\title{
Ameliorative Effects of Rhamnus Fruit (Ziziphus spina-christi L.) and Zinc on Sodium Fluoride-Induced Oxidative Stress in Rats.
}

\section{${ }^{1}$ Nanees Y.E., Awad, ${ }^{2}$ Rania Shams El deen Fakher Eldeen.}

${ }^{1}$ Home Economics Dept., Faculty of Specific Education, Mansoura University, Egypt

${ }^{2}$ Home Economics Department, Faculty of Specific Education, Tanta University .Egypt.

\begin{abstract}
Background: Fluoride is widely distributed in nature in many forms and its compounds are being used extensively. Increased oxidative stress is proposed to mediate the toxic effects of fluoride on soft tissues. Antiinflammatory and antioxidant properties have been describedrom species of the Rhamnaceae family. Aim of the study: Accordingly, this research was conducted to investigate the possible protective effects of rhamnus fruit Ziziphus spina-christi L. (Powder and extract), zinc and their co-treatment against sodium fluoride $(\mathrm{NaF})$-induced oxidative stress in male albino rats. Materials and methods: Thirty five rats were divided into 7 equal groups. Group 1 served as negative control group fed on the basal diet. Group 2: positive control group was given $\mathrm{NaF}(10 \mathrm{mg} / \mathrm{kg})$ orally once daily for 2 weeks. Group 3: zinc $20 \mathrm{mg} / \mathrm{Kg}$ b.wt/ rats. Group 4: fed on the formulated diet with 5\% rhamnus fruit powder. Group 5: given orally rhamnus extract at dose of $5 \mathrm{ml}$. Group 6: 5\% rhamnus fruit powder +zinc and Group 7: $5 \mathrm{ml}$ of rhamnus fruit extract +zinc. At the end of the experiment, all animals were sacrificed and blood samples were obtained for assessment of serum total cholesterol, HDL-C, LDL-C, VLDL-C and triglycerides levels in addition to liver and kidney functions. Oxidative indices including total antioxidant status (TAS), total oxidant status (TOS), kidney TAS and TOS. As well as, kidneys histopathological changes were assessed. Results: NaF intoxicated groups showed significant alterations of biochemical indices with significantly decreased in TAS and TOS levels. Conclusions: The obtained results showed that $\mathrm{NaF}$ intoxication caused hepatic and renal damage by increasing oxidative stress and suggested a possible protective effect of rhamnus fruits and zinc administration against fluoride-induced oxidative stress.
\end{abstract}

Keywords: Na Fluoride, Rhamnus, Zinc, Oxidative $\underline{\text { Stress, }}$ TAS, TOS. 


\section{Introduction}

Fluoride $(\mathrm{F}-)$ is an essential trace element that, in low concentrations ${ }_{L}$ has been proven to be beneficial for teeth and bone development (Pendrys, 2001). It is widely distributed in the environment in different forms and its compounds are extensively used. Typically, water consumption_is the largest contributor to daily $\mathrm{F}$ intake either due to runoff of $\mathrm{F}$ - containing rocks and soils into groundwater or artificial fluoridation of drinking water in some areas (ATSDR, 2003). The permissible amount of fluoride in drinking water is $0.5-1.5 \mathrm{mg} / \mathrm{L}$ (Cotruvo, 2017 and Fallahzadeh et al., 2018). Furthermore, $\mathrm{F}-$ anions are incorporated in various insecticides, Teflon-lined cookware (NRC, 2006), air (due to gaseous industrial waste) (Nabavi et al., 2012) dietary supplements and in drugs designed to reduce dental decay (Fallahzadeh et al., 2018). the consumption of fluoride became uncontrolled and unpredictable often exceeding its therapeutic window (Natalia and Gennadii, 2012). The excessive consumption of fluoride results in fluorosis as a serious health problem (Madhusudhan et al., 2010) which linked to reduce antioxidant defense and increases oxidative stress of brain, liver, kidney and spinal cord (Strunecka and Strunecky, 2020 and Wang and Li, 2002).), a slow degenerative diseases, affecting teeth and bone tissues (Sarkar et al., 2014), as well as inducing neurological defect (Malin and Christine, 2015 and Kumar et al., 2020). Numerous investigations have established that the toxicity of fluoride as fluoride intoxication leads to the down-regulation of antioxidant enzymes (Vani and Reddy, 2000), an increase in relative oxygen species (ROS), and oxidative stress (Ghosh et al., 2002). The pro-oxidant/ antioxidant imbalance caused by fluoride intoxication may lead to multi-organ dysfunctions (Chlubek, 2003). Excessive ROS production and/or diminished antioxidant defenses have been implicated in cancer, diabetes, and cardiovascular diseases (Fatehi-Hassanabad et al., 2010; Montezano and Touyz, 2012 and Storz, 2006). $\mathrm{NaF}$ administration increased levels of lipid peroxidation and reduced SOD and catalase activities. Furthermore, glutathione levels in erythrocytes diminished after $\mathrm{NaF}$ exposure, suggesting an induction of oxidative stress (Nabavi et al., 2013). Moreover, Al-Sabaawy and Al-Kaisie (2020) reported that $\mathrm{NaF}$ may reduce the efficiency of male reproductive system and reduce the levels of sexual hormones in rats. However, zinc antagonizes oxidative stress, apoptosis and cell cycle changes induced by excess fluoride (Yu et al., 2006).

Rhamnus (Ziziphus spina-christi L.) belongs to the Rhamnaceae family that produces small orange-yellow fruits, tasted like a mixture of dates and apples and was usually eaten fresh or dried (Bukar et al., 2015). It is grows 
wild in Egypt especially, in Sinai. Usually in Arabic the fruits have the name of the tree, but in the case of Z. spina-christi, the tree is called siddir and the fruit nabag indicating the specific importance of this plant to local people (Michel $\boldsymbol{e t}$ al., 2011 and Saied et al., 2008). It is shown to have antiviral, antifungal, antibacterial, laxative, purgative and depurative activities and used in the Egyptian folk medicine for treatment of several diseases including gastrointestinal tract ailments, diabetes and diarrhea (Amin and Ghoneim, 2009; Michel et al., 2011 and Mubaraki et al., 2017). Recently, hypoglycemic, hypotensive, hepatoprotective, anti-inflammatory, antioxidant, free radical scavenging, antibactericidal, antimutagenic as well as antiproliferative, pro-apoptotic activity in human cancer cell lines and antigenoapoptosis-inducing properties have been described for species of Rhamnaceae family (Almeer et al., 2018 ; Campbell et al., 2019; Comlekcioglu et al., 2017; Chen et al., 2018; Dkhil et al., 2018; Guizani et al., 2013; Hemeg et al 2020 and Jafarian et al., 2014).

There is an increasing interest in the natural antioxidants contained in medicinal and dietary plants, which are candidates for the prevention of oxidative damages. The genus Zizyphus (Rhamnaceae) is characterized from a phytochemical point of view by the abundance of phenolic substances, especially flavonoids, anthraquinones and tannins (Shahat et al., 2001 and Tripathi et al., 2001), which are described by numerous authors as antioxidant molecules (Kim et al., 2020; Moreira et al., 2018; Park et al., 2004 and Vaya et al., 2003). The active constituents of Ziziphus spina-christi includes triterpenoid sapogenins, geranyl acetate, sterols, saponins, methyl hexadecanoate, peptide, cyclopeptide alkaloids, methyl octadecanoate, tannines, and flavonoids (such as rutin and quercetin derivatives) (Almeer et al., 2018; Jafarian et al., 2014 and Kadioglu et al., 2016). Administration of Ziziphus spina-christi resulted in a greater reduction of inflammatory colonic injury, restored the balance between the oxidants and antioxidants and effectively modulated the mRNA expression of redox-sensitive transcription factors; therefore, it could be considered as an alternative and/or additive therapeutic approach for the management of inflammatory disease (Almeer et al., 2018). Tessema and Molla (2021) revealed that the methanolic extract of crude rhamnus leaves can help the healing of wounds as evidenced by an increase in wound contraction rate and tensile strength, decrease in Epithelialization period. Ghaffari et al., (2021) concluded that the mechanism of action has occurred through the Bax-independent apoptotic pathway in breast cancer MCF-7 cells and inhibited cells proliferation after exposed to Ziziphus spina-christi leaf extracts. Tacherfiout et al., (2018) suggested that rhamnus leaves are rich in 
flavonoids and flavonoid derivatives with an anti-hyperlipidemic effect in vivo and in hepatic cells.

The aim of this study was to characterize the phenolic compounds in rhamnus fruit (Ziziphus spina Christi) by HPLC, and explore the effect of rhamnus fruit (powder and extract), zinc and their co-treatment against sodium fluoride $(\mathrm{NaF})$-induced oxidative stress in male albino rats.

\section{Materials:}

\section{MATERIALS AND METHODS}

Rhamnus fruits: Rhamnus fruits were obtained from the local market in Cairo city, Egypt.

Basal diet: Casein, vitamins, minerals and cellulose were obtained from ElGomhariya Company for Trading Drugs, Chemicals and Medical Instruments, Cairo, Egypt. While starch and corn oil were obtained from local market.

Zinc: Octozinic capsules produced by October pharma S.A.E and contain 110 zinc sulphate heptahydrate. The human therapeutic dose of zinc sulphate heptahydrate was converted to rat dose according to Paget and Barnes, (1964) that was $20 \mathrm{mg} / \mathrm{Kg}$ body weight, dissolved in distilled water and given to rats by oral intubations.

Sodium fluoride: Sodium fluoride was purchased from Sigma Aldrich Chemical Co.

Rats:Thirty-five mature male albino rats of Sprague - Dawley strain weighing $110 \pm 5$ g. at age of 9-12 weeks were obtained from Laboratory of Animal Colony, Helwan, Egypt.

\section{Methods:}

Fresh rhamnus fruits were washed and cleaned with water and dehydrated into air circulated oven at $45^{\circ} \mathrm{C}$ for $24 \mathrm{hrs}$. Then, dried fruit was crushed to powder. Part of the rhamnus dried powder was added to the diet at a level of $5 \%$ of the diet. The other part of dried powder was used for the preparation of ethanolic extract, where, $100 \mathrm{~g}$ of rhamnus fruits powdered was soaked in 500 $\mathrm{ml}$ of $80 \%$ ethanol with frequent agitation. Clarification was then carried out using vacuum filtration through filter paper whatman number 2 . The resultant extract was concentrated to dryness using a rotary evaporator under reduced pressure at a temperature of $40^{\circ} \mathrm{C}$.

Phytochemical analysis of Rhamnus fruits: Types and concentrations of polyphenolic compounds were estimated as recommended by (Goupy et al., 1999). At Laboratory of Food Technology Research Institute, Agriculture Research Center, Egypt. 


\section{Experimental design:}

The rats were housed in stainless steel cages with wire mesh bottoms and maintained in temperature and humidity control with $12 \mathrm{hrs}$ light / dark cycle. All rats were allowed to freely access drinking of water and basal diet for seven days adjustment to the laboratory environment. The basal diet comprised of casein $(200 \mathrm{~g} / \mathrm{kg})$, cornstarch $(497 \mathrm{~g} / \mathrm{kg})$, sucrose $(100 \mathrm{~g} / \mathrm{kg})$, cellulose $(30 \mathrm{~g} / \mathrm{kg})$ ,corn oil $(50 \mathrm{~g} / \mathrm{kg})$, mineral mixture $(100 \mathrm{~g} / \mathrm{kg})$, vitamin mixture $(20 \mathrm{~g} / \mathrm{kg})$ and DL-methionine $(3 \mathrm{~g} / \mathrm{kg})$ according to NRC, (1995). The rats were randomly divided into 7 groups (each of 5 rats) as follows:

Group 1: normal control rats fed on the basal diet.

Group 2: positive control rats were given $\mathrm{NaF}(10 \mathrm{mg} / \mathrm{kg}$ b.wt) orally once daily for 2 weeks as described by Blaszczyk, et al., (2011)

Group 3: Naf + fed on the basal diet and given zinc $20 \mathrm{mg} / \mathrm{Kg}$ b.wt/rats orally.

Group 4: Naf + fed on formulated diet with $5 \%$ rhamnus fruits powder

Group 5: Naf $+5 \mathrm{ml}$ of rhamnus fruits extract

Group 6: Naf $+5 \%$ rhamnus fruits powder +zinc

Group 7: Naf $+5 \mathrm{ml}$ of rhamnus fruits extract +zinc

The net food intake and gained body weight were used for the calculation of Food and protein efficiency ratio (FER\&PER) according to (Chapman et al., 1950).

\section{Tissue preparation:}

The kidney was removed, washed and perfused with normal saline to remove residual blood. Kidney tissues were homogenized (model TH 220, OMNI, Warrenton, VA, USA) 1:10 (w/v) in ice-cold $140 \mathrm{mM}$ potassium chloride at $\mathrm{pH}$ 7.4. The homogenates tissues were centrifuged at $3000 \mathrm{rpm}$ for $10 \mathrm{~min}$ at $4{ }^{0} \mathrm{C}$, and the supernatants were removed and stored at $-80{ }^{\circ} \mathrm{C}$ until analysis of oxidative stress parameter are performed.

\section{Biochemical analysis:}

At the end of the experimental period (6 weeks), rats were sacrificed after overnight fasting under ether anesthesia. Blood samples were collected from hepatic portal vein in a clean dry centrifuge tube. Then blood samples were left to clot at room temperature for 15 minutes, and centrifuged at $3000 \mathrm{rpm}$ for 20 minutes for serum separate. Serum was carefully separated and transferred into clean quite fit plastic tubes and kept frozen at $-20^{\circ} \mathrm{C}$ until the time of biochemical analysis.

\section{Determination of serum lipids:}

Serum levels of triglycerides were determined according to the method of Fossati and Prencipe, (1982). Total cholesterol was determined by 
colorimetric method according to Allian et al., (1974). High density lipoproteins cholesterol (HDL-c) were determined according to the method of Gordon and Amer, (1977). Very low density lipoproteins cholesterol (VLDLc) and low density lipoproteins cholesterol (LDL-c) were determined according to the method of Lee and Nieman, (1996).

\section{Determination of Total antioxidant status and total oxidation status:}

Total antioxidant status (TAS) was measured using a commercially available kits from Rel Assay Diagnostics (Gaziantep, Turkey). The method was based on the reduction of colored 2.20-azino-bis(3-ethylbenzotiazoline-6sulfonic acid) (ABTS) radical to a colorless reduced form by antioxidants present in the sample. Absorbance was measured spectrophotometrically at a wavelength of $660 \mathrm{~nm}$. The method was calibrated using the vitamin E analog trolox, and data were expressed as mmol Trolox equivalent (eq.) per liter (mmol Trolox eq./L) (Erel, 2004).

Total antioxidant status (TOS) was measured using a commercially available kit from Rel Assay Diagnostics (Erel, 2005). The method was based on the principle that the oxidants in the sample oxidized ferrous ions, previously bounded to a chelator to ferric ions. In the acidic medium of the assay, these ferric ions formed a colored complex with a chromogen. The color intensity was measured spectrophotometrically at a wavelength of $530 \mathrm{~nm}$. This assay was calibrated with hydrogen peroxide $\left(\mathrm{H}_{2} \mathrm{O}_{2}\right)$, and the results were expressed as $1 \mathrm{~mol} \mathrm{H}_{2} \mathrm{O}_{2}$ eq./L.

\section{Determination of liver and kidney functions:}

Serum alanine aminotransferase (ALT) and aspartate aminotransferase (AST) were estimated according to Reitman and Frankel, (1957), alkaline phosphatase (ALP) and lactate dehydrogenase (LDH) were determined according to Bergmeyer and Horder, (1980) and Vassault, (1983), respectively. Total bilirubin was measured according to the method of Reitman and Frankel, (1957). Serum creatinine and Uric acid were determined according to the methods described by Bartles et al., (1972 and Haisman and Muller (1977), respectively.

\section{Histopathological examination:}

The kidney was subjected to histological examination according to Frankel and Reitman (1963).

\section{Statistical analysis:}

The obtained data were statistically analyzed using computerized SPSS. Effects of different treatments were analyzed by one way ANOVA (Analysis of 
variance) test using Duncan's multiple range test and $\mathrm{p}<0.05$ was used to indicate significance between different groups (Snedecor and Cochran, 1967).

\section{RESULTS AND DISCUSSION}

\section{Polyphenol fractions of Rhamnus fruit (Ziziphusspina Christi):}

The phytochemical study of rhamnus fruit showed the presence of various qualitative and quantities of total polyphenolic compounds Table 1. As it can be seen, rhamnus fruit contained higher amounts of chlorogenic acid, nimbolide, vanillic acid, ferulic acid, phenolic acids, $p$-coumaric acid, pyrocatechol, 2', 3'dehydrosalannol, quercetin-3-rhamnoside, caffeic acid, gallic acid, rutin and epoxy-azadiradione, respectively. These results were consistent with Marzouk et al., (1999) who reported that flavonol glycosides represent an important part in the polyphenolic compounds contained in rhamnus fruits. Cuoco et al., (2014) revealed that the flavonol compounds present in green species of rhamnus fruits were quercetin, kaempferol, isorhamnetin, rhamnetin, rhamnocitrin and rhamnazin. Rocchetti, et al., (2019) showed that mature ramnus fruits were rich source of flavonols (glycosidic forms of quercetin and kaempferol). The fresh nabak fruit (Ziziphus spina-christi) contained phenolic as $1644 \mathrm{mg}$ GAE/100 g (Guizani et al., 2013). Its active constituents include flavonoids such as rutin and quercetin derivatives (Jafarian et al., 2014). Moreover, Almeer et al., (2018) characterized polyphenolic compounds of Ziziphus spina-christi fruit extract as catechin, gallic acid, ellagic acid, chlorogenic acid, rutin, isoquercitrin, quercetin, and kaempferol. Those active compounds have many biological activities: for example Chlorogenic acid can mitigate oxidative and infammatory stresses (Dkhil et al., 2018 and Liang and Kitts 2015), quercetin, apigenin, and kaempferol are potent antioxidants (AlOlayan et al., 2014). Numerous studies have confirmed the abundant of kaempferol and Quercetin in Rhamnaceae family (Boussahel et al., 2013; Chaouche et al., 2020; Moussi et al., 2015 and Zeouk, et al., 2020). The interesting antioxidant potency of this species has been also demonstrated (Ammar et al., 2018 and Bhouri et al., 2011). Moussi et al., (2015) identified phenolic compounds of leaves extract of Rhamnus alaternus $\mathrm{L}$ were rutin, quercetin-3-rhamnoside, kaempferol, $p$-coumaric acid, ferulic acid, gallic acid, luteolin and anthraquinones. These phytochemical families have been demonstrated to play a role in antioxidant mechanism of action due to their molecular structures (Ammar et al. 2018; Huang and Frankel, 1997 and Montoro et al., 2005). Flavonoids as putative examples were considered as good electron and hydrogen donors; this character brings to the end of radical chain through converting free radicals to more stable compounds (Kelly, 2010). Bhouri et al., (2012) isolated two antioxidant flavonoids namely Kaempferol 3- 
O-beta isorhamninoside and Rhamnocitrin 3-O-beta isorhamninoside which had capacities to transfer electron leading to an attack against free radicals and then combating cellular damage.

Table (1): Types and amount of polyphenol fractions of rhamnus fruit (Ziziphus spina Christi)

\begin{tabular}{|l|l|}
\hline Phenolic Compounds & Total Phenols (ppm) \\
\hline Caffeic acid & 453.14 \\
\hline Chlorogenic acid & 2519.57 \\
\hline Ferulic acid & 808.26 \\
\hline p-coumaric acid & 624.80 \\
\hline Gallic acid & 445.23 \\
\hline Vanillic acid & 1215.51 \\
\hline Pyrocatechol & 599.16 \\
\hline Pyrogallol & 18.45 \\
\hline quercetin-3-rhamnoside & 504.50 \\
\hline Rutin & 358.23 \\
\hline Epoxy-azadiradione & 113.40 \\
\hline Nimbolide & 2514.15 \\
\hline Myricetin & 29.00 \\
\hline Quercetin & 96.30 \\
\hline Kaempferol & 57.40 \\
\hline phenolic acids & 682.35 \\
\hline $2^{\prime}, 3^{\prime}$-dehydrosalannol & 510.37 \\
\hline
\end{tabular}

The effect of rhamnus fruit (powder and extract), zinc and their cotreatment on body weight, body weight gain, food intake and feed efficiency ratio (FER).

Effect of rhamnus fruits (powder and extract), zinc and their co-treatment against sodium fluoride $(\mathrm{NaF})$-induced oxidative stress on body weight, body weight gain, food intake, feed efficiency ratio (FER) and protein efficiency ratio (PER) are presented in Table 2. The initial body weights of rats were similar in all groups and all of them gave positive body weight gain at the end of the experiment. Meanwhile, NaF-treated group recorded the lowest body weight gain and food intake as compared with all groups. It was noticed that the treated rats with $\mathrm{NaF}+\mathrm{Zn}+$ rhamnus fruit (powder and extract were the best mitigating ability against $\mathrm{NaF}$ toxicity; although, all of rhamnus fruits (powder and extract) and zinc showed a positive and protective effect on $\mathrm{NaF}$ toxicity. These results are in accordance with Nageshwar et al., (2017) and Kumar et al., (2020) who reported that the body weight of rats treating with NaF significantly decreased, compared with the negative control group. The decreased body weight might be 
due to reduced food intake or disturbed protein and energy metabolism after fluoride ingestion (Chinoy et al., 1991). Yossef et al., (2011) concluded that Ziziphus spina-christi fruit significantly increased the body weight and weight gain, which decreased by carbon tetrachloride (CCL4). In contrast, Lopes et al., (2020) reported that during the experimental period, the fluoride exposure did not impair the body weight gain and showed no difference in the beginning, middle, and end of exposure protocol $(\mathrm{p}=0.05)$.

Table (2): Effect of Rhamnus fruit (powder and extract), zinc and their co-treatment on Body weight, body weight gain, food intake and feed efficiency ratio (FER) of the study groups.

\begin{tabular}{|c|c|c|c|c|c|c|}
\hline Groups & $\begin{array}{l}\text { Initial } \\
\text { Weight } \\
\text { (g) }\end{array}$ & $\begin{array}{l}\text { Final } \\
\text { Weight } \\
\text { (g) }\end{array}$ & $\begin{array}{l}\text { Weight } \\
\text { Gain } \\
\text { (g) }\end{array}$ & $\begin{array}{l}\text { Food } \\
\text { Intake } \\
(\mathrm{g} / \mathrm{d}))\end{array}$ & FER & PER \\
\hline $\begin{array}{l}\text { G(1): Negative } \\
\text { control (N-) }\end{array}$ & $\begin{array}{l}110.55 \\
\pm \\
3.67^{\mathrm{a}}\end{array}$ & $\begin{array}{l}203.47 \\
\pm \\
13.01^{\mathrm{a}}\end{array}$ & $\begin{array}{l}92.92 \\
\pm \\
11.33^{\mathrm{a}}\end{array}$ & $\begin{array}{l}16.65 \\
\pm \\
2.11^{\mathrm{a}}\end{array}$ & $\begin{array}{l}0.093 \\
\pm \\
0.001^{\mathrm{a}}\end{array}$ & $\begin{array}{l}0.046 \\
\pm \\
0.03^{\text {a }}\end{array}$ \\
\hline $\begin{array}{l}\text { G(2): positive } \\
\text { control }(\mathrm{N}+)\end{array}$ & $\begin{array}{l}110.41 \\
\pm \\
3.50^{\mathrm{a}} \\
\end{array}$ & $\begin{array}{l}154.71 \\
\pm \\
12.13^{\mathrm{b}} \\
\end{array}$ & $\begin{array}{l}44.30 \\
\pm \\
7.71^{b} \\
\end{array}$ & $\begin{array}{l}14.20 \\
\pm \\
2.17^{\mathrm{a}}\end{array}$ & $\begin{array}{l}0.051 \\
\pm \\
0.002^{b}\end{array}$ & $\begin{array}{l}0.025 \\
\pm \\
0.01^{\mathrm{b}}\end{array}$ \\
\hline $\begin{array}{l}\text { G(3): zinc } 20 \\
\text { mg/Kg } \\
\text { b.w./rats }\end{array}$ & $\begin{array}{l}112.14 \\
\pm \\
3.41^{\mathrm{a}}\end{array}$ & $\begin{array}{l}190.11 \\
\pm \\
12.38^{\mathrm{a}}\end{array}$ & $\begin{array}{l}80.97 \\
\pm \\
10.14^{\mathrm{a}}\end{array}$ & $\begin{array}{l}15.95 \\
\pm \\
1.99^{\mathrm{a}}\end{array}$ & $\begin{array}{l}0.084 \\
\pm \\
1.002^{\mathrm{a}}\end{array}$ & $\begin{array}{l}0.042 \\
\pm \\
0.02^{\text {a }}\end{array}$ \\
\hline $\begin{array}{ll}\mathbf{G ( 4 ) :} & \mathbf{5 \%} \\
\text { Rhamnus } & \\
\text { powder } & \end{array}$ & $\begin{array}{l}109.14 \\
\pm \\
2.45 \mathrm{a}\end{array}$ & $\begin{array}{l}189.71 \\
\pm \\
11.22 \mathrm{a}\end{array}$ & $\begin{array}{l}80.57 \\
\pm \\
8.17 \mathrm{a}\end{array}$ & $\begin{array}{l}15.90 \\
\pm \\
2.11 \mathrm{a}\end{array}$ & $\begin{array}{l}0.084 \\
\pm \\
0.003 \mathrm{a}\end{array}$ & $\begin{array}{l}0.042 \\
\pm \\
0.03 \mathrm{a}\end{array}$ \\
\hline $\begin{array}{l}\text { G (5): } 5 \mathrm{ml} \\
\text { Rhamnus } \\
\text { extract }\end{array}$ & $\begin{array}{l}113.33 \\
\pm \\
2.99 \mathrm{a}\end{array}$ & $\begin{array}{l}199.41 \\
\pm \\
13.78 \mathrm{a}\end{array}$ & $\begin{array}{l}91.08 \\
\pm \\
10.22 \mathrm{a}\end{array}$ & $\begin{array}{l}16.35 \\
\pm \\
2.91 \mathrm{a}\end{array}$ & $\begin{array}{l}0.092 \\
\pm \\
0.001 \mathrm{a}\end{array}$ & $\begin{array}{l}0.046 \\
\pm \\
0.02 \mathrm{a}\end{array}$ \\
\hline $\begin{array}{l}\text { G (6): } 5 \% \\
\text { Rhamnus } \\
\text { powder +zinc }\end{array}$ & $\begin{array}{l}110.22 \\
\pm \\
3.11 \mathrm{a} \\
\end{array}$ & $\begin{array}{l}201.14 \\
\pm \\
12.35 \mathrm{a}\end{array}$ & $\begin{array}{l}90.92 \\
\pm \\
11.11 \mathrm{a}\end{array}$ & $\begin{array}{l}16.55 \\
\pm \\
2.18 \mathrm{a} \\
\end{array}$ & $\begin{array}{l}0.091 \\
\pm \\
0.001 \mathrm{a}\end{array}$ & $\begin{array}{l}0.045 \\
\pm \\
0.04 \mathrm{a}\end{array}$ \\
\hline $\begin{array}{l}\text { G (7): } 5 \mathrm{ml} \\
\text { Rhamnus } \\
\text { extract +zinc }\end{array}$ & $\begin{array}{l}110.34 \\
\pm \\
3.14 \mathrm{a}\end{array}$ & $\begin{array}{l}205.11 \\
\pm \\
14.41 \mathrm{a}\end{array}$ & $\begin{array}{l}94.77 \\
\pm \\
11.21 \mathrm{a}\end{array}$ & $\begin{array}{l}16.75 \\
\pm \\
2.81 \mathrm{a}\end{array}$ & $\begin{array}{l}0.094 \\
\pm \\
0.003 \mathrm{a}\end{array}$ & $\begin{array}{l}0.047 \\
\pm \\
0.03 \mathrm{a}\end{array}$ \\
\hline
\end{tabular}

Mean values \pm SD in each column having different superscript $(a, b$,$) are significant.$

Effect of Rhamnus fruit (powder and extract), zinc and their cotreatment on lipid profile:

Table (3) shows the changes in serum lipid profiles as a result of different treatment. It could be observed that $\mathrm{NaF}$ - treated group represented significant increases in serum TC, TG, LDL-C and VLDL-C as compared with negative control and other treatment groups. On the other hand NaF- treated group showed significant decreases in serum HDL-C as compared with all treated groups with fruits and Zn. The increment in serum TC, TG, LDL-C and VLDL- 
$\mathrm{C}$ were ameliorated in all groups that received rhamnus fruits (powder and extract) and zinc. However, G 3 of treated rats with zinc $(20 \mathrm{mg} / \mathrm{Kg} \mathrm{b.w.)}$ showed the lowest effect in the lipid improvement against NaF toxicity. From these data, it is clear that G6 and G7 had the greatest effect in the decrement of TC, TG, LDL-C and VLDL-C and the increment of HDL-C as compared with positive control G2 and in some parameters they had no significant changes as compared with the negative control G1.

In the current study, sodium fluoride administration led to significant increases in serum cholesterol and triglycerides, compared with the negative control groups, these $\mathrm{NaF}$-alteration in lipid profile are in agreement with the obtained results by Al-Harbi et al.,(2014), Khudair and Aldabaj (2014) and Abou Anza and Salah Eldin (2015). Conflicting results were also obtained by Kanbur et al. (2009) who reported lowering in plasma cholesterol and TG levels following $\mathrm{NaF}$ administration. Enzymes inhibited by fluoride (triglyceride lipase, unspecific esterase and pyrophosphates) were suggested to be responsible for the rise in serum triglycerides and cholesterol. Moreover, fluoride was found to cause hypercholesterolemia due to lowering of insulin level (Garcia-Montalvo et al., 2009). Also, $\mathrm{NaF}$ intoxication increased lipid peroxidation and loss of membrane integrity might be important in altered lipid metabolism and closely associated with the observed hyperlipidemia (AbdelWahab, 2013). Yossef et al., (2011) concluded that Ziziphus spina-christi fruit extract restores significantly normal levels of serum cholesterol, triglyceride, LDL and VLDL as compared to the elevated level induced by CCL4. Tacherfiout et al., (2018) found that oral treatment with $200 \mathrm{mg} / \mathrm{kg}$ b.wt and $400 \mathrm{mg} / \mathrm{kg}$ b.wt of rhamnus leaves extract decreased serum triacylglycerols by $70 \%$ and $42 \%$, and serum total cholesterol by $60 \%$ and $40 \%$, respectively, relative to the hyperlipidemic control group. Flavonoids derivatives from R. alaternus leaves showed a similar positive impact on murine preadipocyte 3T3L1 cellular model. The hypolipidemic activity of rhamnus fruit is likely to be due to its flavonoids content. Flavonoids or flavonoid-rich extracts have been reported to lower serum lipids in diverse animal models of hyperlipidemia, through a variety of mechanisms. These include: down-regulating the production of intestinal-associated lipoprotein apoB48 (Ma et al., 2015), inhibiting the activity of hepatic HMG-CoA reductase (Khamis et al., 2017 and Kuang et al., 2017), inhibiting hepatic lipogenesis through suppressed expression of SREBP1 and fatty acid synthase (Bao et al., 2016 and Kuang et al., 2017) and stimulating hepatic fatty acid oxidation (Chang et al., 2011 and Mulvihill et al., 2011). 
Table (3): Effect of Rhamnus (powder and extract), zinc and their cotreatment on Lipid profile.

\begin{tabular}{|l|c|c|c|c|c|}
\hline \multicolumn{1}{|c|}{ Gariables } & $\begin{array}{c}\text { Total Cholestrol } \\
\text { TC } \\
(\mathrm{mg} / \mathrm{dl})\end{array}$ & $\begin{array}{c}\text { Triglycerides } \\
\text { TG } \\
(\mathrm{mg} / \mathrm{dl})\end{array}$ & $\begin{array}{c}\text { HDL-c } \\
(\mathrm{mg} / \mathrm{dl})\end{array}$ & $\begin{array}{c}\text { LDL-c } \\
(\mathrm{mg} / \mathrm{dl})\end{array}$ & $\begin{array}{c}\text { VLDL-c } \\
(\mathrm{mg} / \mathrm{dl})\end{array}$ \\
\hline \begin{tabular}{l|c|c|c|c|} 
G(1): Negative \\
control (N-)
\end{tabular} & $85.37 \pm$ & $67.13 \pm$ & $39.50 \pm$ & $29.24 \pm$ & $13.51 \pm$ \\
\hline G(2): positive control & $4.16 \mathrm{~d}$ & $5.97 \mathrm{~d}$ & $2.29 \mathrm{a}$ & $9.99 \mathrm{e}$ & $0.59 \mathrm{~d}$ \\
(N+) & $9.71 \mathrm{a}$ & $106.55 \pm$ & $25.23 \pm$ & $78.87 \pm$ & $21.47 \pm$ \\
\hline G(3): zinc 20 mg/Kg & $110.46 \pm$ & $89.66^{\mathrm{a}}$ & $2.37 \mathrm{c}$ & $6.55^{\mathrm{a}}$ & $2.13 \mathrm{a}$ \\
b.w./rats & $8.26 \mathrm{~b}^{* *}$ & $6.14 \mathrm{~b}$ & $31.17 \pm$ & $60.14 \pm$ & $17.85 \pm$ \\
\hline G(4): 5\% Rhamnus & $98.75 \pm$ & $78.67 \pm$ & $32.53 \pm$ & $48.57 \pm \mathrm{b}$ & $0.63 \mathrm{~b}$ \\
powder & $7.44 \mathrm{c}$ & $5.22 \mathrm{bc}$ & $3.02 \mathrm{~b}$ & $3.34 \mathrm{c}$ & $15.79 \pm$ \\
\hline G (5): 5 ml Rhamnus & $93.27 \pm$ & $72.48 \pm$ & $37.70 \pm$ & $39.91 \pm$ & $15.17 \pm$ \\
extract & $6.89 \mathrm{c}$ & $5.42 \mathrm{~cd}$ & $2.07 \mathrm{a}$ & $3.66 \mathrm{~d}$ & $0.28 \mathrm{~cd}$ \\
\hline G (6): 5\% Rhamnus & $91.27 \pm$ & $70.48 \pm$ & $37.99 \pm$ & $37.51 \pm$ & $14.91 \pm$ \\
powder +zinc & $6.89 \mathrm{c}$ & $5.42 \mathrm{~cd}$ & $2.07 \mathrm{a}$ & $3.66 \mathrm{~d}$ & $0.28 \mathrm{~cd}$ \\
\hline G (7): 5 ml Rhamnus & $90.66 \pm$ & $69.18 \pm$ & $38.10 \pm$ & $35.21 \pm$ & $14.17 \pm$ \\
extract +zinc & $6.89 \mathrm{c}$ & $5.42 \mathrm{~cd}$ & $2.07 \mathrm{a}$ & $3.66 \mathrm{~d}$ & $0.28 \mathrm{~cd}$ \\
\hline
\end{tabular}

Mean values \pm SD in each column having different superscript $(a, b$,$) are significant.$

\section{Effect of Rhamnus fruit (powder and extract), zinc and their co- treatment on liver and kidneys functions:}

Table (4) shows a comparison between negative control group, NaFtreated group, $\mathrm{NaF}+\mathrm{Zn}$-treated group, $\mathrm{NaF}+$ rhamnus fruits (powder and extract)-treated groups and $\mathrm{NaF}+\mathrm{Zn}+$ rhamnus fruits (powder and extract)treated groups, as regards of liver and kidney parameters. Significant increases were noticed in NaF-treated group in compare to the negative control group and all treatment groups as regards of all experimental parameters except, total bilirubin it showed a significant decrease. The most significant amelioration was observed in the $\mathrm{NaF}+\mathrm{zn}+$ rhamnus fruits (powder and extract)-treated groups (G6 and G7) at the level of serum biomarkers related to hepatic dysfunction (AST, ALT, ALP and lactate dehydrogenase activities and total bilirubin level) and kidney function (creatinine and uric acid levels) suggesting a potential protective role of rhamnus fruit against $\mathrm{NaF}$-induced hepatic damage. These results are in parallel with those obtained by Abou Anza and Salah Eldin (2015) and Pratt and Kaplan, (2005) who showed that oral administration of $\mathrm{NaF}$ induced a significant increase in serum liver enzymes (AST, ALT, ALP and total bilirubin and kidney enzymes; creatinine and Urea (Iheka et al., 2015). These indices usually reflect hepatocyte integrity and cholestasis and their elevation indicates hepatocellular damage. AL-Harbi $\boldsymbol{e t}$ al., 2014; Atmaca et al., 2014 demonstrated that the induction of both pathomorphological and metabolic changes in the liver by exposure to fluoride. 
As a site of active metabolism, the liver can be especially susceptible to fluoride toxicity (Shashi and Thapar, 2001). NaF-induced cytotoxicity and necrotic death of hepatocytes can be related to toxic fluoride effects ultimately leading to cell death. These cellular events include an induction of inflammatory reactions, inhibition of protein synthesis and cell cycle progression, oxidative stress, and DNA damage. The molecular mechanisms underlying fluorideinduced apoptosis include the stimulation of $\mathrm{G}$ protein dependent signaling systems, oxidative stress, ATP depletion, activation of the cell surface death receptors, disruption of outer mitochondria membrane, alterations in the ratio of anti-apoptotic-apoptotic Bcl-2 proteins, upregulation of p53 expression, expression of apoptosis-related genes, endoplasmic reticulum stress and disturbances in protein synthesis (Ghosh et al., 2008 and Agalakova and Gusev, 2013). Ziziphus spina-christi fruit extract restores normal levels of ALT, AST and ALP in serum reduced the CCL4-induced levels of ALT and AST (Shen $\boldsymbol{e t}$ al. 2009 and Yossef $\boldsymbol{e}$ al., 2011). It can be concluded that $\mathrm{NaF}$ induced a hepatic damage, which represented in elevating markedly activities of ALT and AST in serum. Guizani et al., (2013) stated that the treatment of rats with $175 \mathrm{mg} \mathrm{GAE} / \mathrm{kg}$ b. wt (per week) Ziziphus spina-christi fruit extract for 16 weeks produced no functional disturbances in liver and kidney and no haematological changes were detected as well as Ziziphus spina-christi fruit significantly ameliorated the Azoxymethane -induced Oxidative Stress.

Absorbed fluoride is carried by the blood, causes metabolic disturbances in the body (Sahay, 1986). The major rout for the removal of fluoride from the body is by the kidney. Kidney is the primary target for fluoride toxicity (Inkiewicz and Krechniak 2003). Disturbances in kidney function influenced by fluoride have been reported by numerous authors (Birkner et al., 2006; Grucka-Mamczar et al., 2003 and Sashi et al., 2002). High concentrations of fluoride usually lead to kidney damage included tubular degeneration, inflammation and fibrosis (Dote et al., 2000). Concurrently, fluoride caused degeneration and necrosis of the tubular cells, renal tubular hyaline casts and glomeruli swelling (Luo et al., 2017) found that fluoride in excess of $12 \mathrm{mg} / \mathrm{kg}$ are induced renal oxidative damage, which was characterized by the alteration of renal function parameters including elevated contents of serum creatinine, serum uric acid, blood urea nitrogen, and the activities of urinary N-acetyl-b-Dglucosaminidase, renal lactate dehydrogenase (LDH), and reduced activities of sodium-potassium adenosine triphosphatase $(\mathrm{Na}+/ \mathrm{K}+$-ATPase $)$ and acid phosphatase (ACP) in the kidney. 
Table (4): Effect of Rhamnus (powder and extract), zinc and their cotreatment on liver and kidney functions

\begin{tabular}{|c|c|c|c|c|c|c|c|}
\hline Kariables & $\begin{array}{l}\text { AST } \\
(\mu / \mathrm{ml})\end{array}$ & $\begin{array}{l}\text { ALT } \\
(\mu / \mathrm{ml})\end{array}$ & $\begin{array}{l}\text { ALP } \\
(\mu / \mathrm{ml})\end{array}$ & $\mid \begin{array}{l}\text { LDH } \\
\text { (Umg/dl) }\end{array}$ & $\begin{array}{l}\text { Total } \\
\text { bilirubin } \\
\text { (mg/dl) }\end{array}$ & $\begin{array}{l}\text { Creatinine } \\
(\mathbf{m g} / \mathbf{d l})\end{array}$ & $\begin{array}{l}\text { Uric acid } \\
(\mathrm{mg} / \mathrm{dl})\end{array}$ \\
\hline $\begin{array}{l}\text { G(1): Negative } \\
\text { control (N-) }\end{array}$ & $\begin{array}{l}41.17 \\
\pm \\
5.81^{\mathrm{b}}\end{array}$ & $\begin{array}{l}13.35 \\
\pm \\
1.12^{\mathrm{b}}\end{array}$ & $\begin{array}{l}30.17 \\
\pm \\
5.66^{b}\end{array}$ & $\begin{array}{l}354 \pm \\
28.11 \mathrm{e}\end{array}$ & $\begin{array}{l}39.50 \pm \\
3.29 \mathrm{a}\end{array}$ & \begin{tabular}{|l}
0.77 \\
\pm \\
$0.01^{\mathrm{b}}$
\end{tabular} & $\begin{array}{l}1.83 \\
0.26^{\mathrm{c}}\end{array}$ \\
\hline \begin{tabular}{|l}
$G(2): \quad$ positive \\
control $(\mathrm{N}+)$
\end{tabular} & $\begin{array}{l}72.39 \pm \\
9.61^{\mathrm{a}^{* *}}\end{array}$ & $\begin{array}{l}28.55 \pm \\
3.35^{\mathrm{a}^{* *}}\end{array}$ & $\begin{array}{l}50.38 \pm \\
5.81^{\mathrm{a}^{* *}}\end{array}$ & $\begin{array}{l}857.56 \pm \\
37.55 \mathrm{a}^{* *}\end{array}$ & $\begin{array}{l}28.23 \pm \\
2.37 \mathrm{c} * *\end{array}$ & $\begin{array}{l}1.95 \\
\pm 0.11^{\mathrm{a}^{* *}}\end{array}$ & $\begin{array}{l}4.41 \\
\pm 1.01^{\mathrm{a}^{* * * *}}\end{array}$ \\
\hline $\begin{array}{ll}\text { G(3):zinc } & 20 \\
\text { mg/Kg b.w./rats }\end{array}$ & $\begin{array}{l}49.37 \\
\pm \\
6.01^{\mathrm{b}}\end{array}$ & $\begin{array}{l}15.71 \\
\pm \\
1.81^{\mathrm{b}}\end{array}$ & $\begin{array}{l}37.80 \\
\pm \\
4.11^{\mathrm{b}}\end{array}$ & $\begin{array}{l}450.14 \pm \\
24.76 b\end{array}$ & $\begin{array}{l}31.17 \pm \\
3.76 \mathrm{~b}\end{array}$ & \begin{tabular}{|l}
0.99 \\
\pm \\
$0.02^{\mathrm{b}}$
\end{tabular} & $\begin{array}{l}2.11 \\
\pm \\
0.81^{\mathrm{b}}\end{array}$ \\
\hline $\begin{array}{l}\text { G(4):5\% } \\
\text { Rhamnus } \\
\text { powder }\end{array}$ & \begin{tabular}{|l}
51.14 \\
\pm \\
$8.10^{b}$
\end{tabular} & \begin{tabular}{|l|}
16.28 \\
\pm \\
$2.01^{b}$
\end{tabular} & \begin{tabular}{|l}
38.73 \\
\pm \\
$4.37^{\mathrm{b}}$
\end{tabular} & $\begin{array}{l}423.57 \pm \\
23.34 \mathrm{c}\end{array}$ & $\begin{array}{l}33.53 \pm \\
3.02 b\end{array}$ & \begin{tabular}{|l}
0.88 \\
\pm \\
$0.12^{b}$
\end{tabular} & \begin{tabular}{|l}
2.41 \\
\pm \\
$0.77^{\mathrm{b}}$
\end{tabular} \\
\hline $\begin{array}{l}\text { G(5):5ml } \\
\text { Rhamnus } \\
\text { extract }\end{array}$ & $\begin{array}{l}48.21 \\
\pm \\
6.15^{b}\end{array}$ & $\begin{array}{l}18.13 \\
\pm \\
3.51^{\mathrm{b}}\end{array}$ & \begin{tabular}{|l}
38.34 \\
\pm \\
$5.01^{\mathrm{b}}$
\end{tabular} & $\begin{array}{l}406.91 \pm \\
21.66 \mathrm{~d}\end{array}$ & $\begin{array}{l}35.70 \pm \\
2.07 \mathrm{a}\end{array}$ & $\begin{array}{l}0.75 \\
\pm \\
0.13^{b}\end{array}$ & $\begin{array}{l}2.17 \\
\pm \\
0.67^{b}\end{array}$ \\
\hline \begin{tabular}{|l|} 
G(6):5\% \\
Rhamnus \\
powder +zinc
\end{tabular} & $\begin{array}{l}40.21 \\
\pm \\
4.13^{b}\end{array}$ & $\begin{array}{l}14.11 \\
\pm \\
3.65^{\mathrm{b}}\end{array}$ & \begin{tabular}{|l}
32.11 \\
\pm \\
$3.11^{\mathrm{b}}$
\end{tabular} & $\begin{array}{l}402.10 \pm \\
22.66 \mathrm{~d}\end{array}$ & $\begin{array}{l}37.10 \pm \\
2.03 \mathrm{a}\end{array}$ & $\begin{array}{l}0.70 \\
\pm \\
0.15^{b}\end{array}$ & $\begin{array}{l}1.74 \\
\pm \\
0.74^{\mathrm{c}}\end{array}$ \\
\hline $\begin{array}{l}\text { G(7):5ml } \\
\text { Rhamnus } \\
\text { extract +zinc }\end{array}$ & \begin{tabular}{|l|}
43.19 \\
\pm \\
$4.61^{\mathrm{b}}$ \\
\end{tabular} & \begin{tabular}{|l|}
15.31 \\
\pm \\
$3.66^{\mathrm{b}}$ \\
\end{tabular} & $\begin{array}{l}35.30 \\
\pm \\
2.99^{\mathrm{b}}\end{array}$ & $\begin{array}{l}396.20 \pm \\
22.66 \mathrm{~d}\end{array}$ & $\begin{array}{l}38.35 \pm \\
2.01 \mathrm{a}\end{array}$ & \begin{tabular}{|l|}
0.98 \\
\pm \\
$0.18^{b}$
\end{tabular} & \begin{tabular}{|l|}
.25 \\
\pm \\
$0.16^{\mathrm{b}}$ \\
\end{tabular} \\
\hline
\end{tabular}

Mean values \pm SD in each column having different superscript $(a, b$,$) are significant.$

AST: aspartate transferase ALT: alanine aminotransferase ALP: alkaline phosphatase LDH: lactate dehydrogenase

Effect of Rhamnus (powder and extract), zinc and their co-treatment on oxidative status levels:

In the present study, exposure to sodium fluoride increased total oxidant status (TOS) antioxidant enzyme and decreased total antioxidant status (TAS) as shown in Table 5, suggesting an impaired function of antioxidant defense system. However, supplementation of $\mathrm{NaF}$ intoxicated groups with rhamnus fruits (powder and extract), zinc and their co-treatment restored antioxidative homeostasis. This was evidenced by increased assayed markers of the endogenous antioxidant system (TAS) with concomitant decrease of markers of oxidative stress mediated damage (TOS).

Numerous studies linked increased oxidative stress to $F$ exposure (Grucka-Mamczar et al., 2009; Nabavi et al., 2013). The measure of total antioxidant capacity (TAC) generally considers the cumulative action of all the antioxidants present in plasma and body fluids, thus provides an integrated parameter rather than the simple sum of measurable antioxidants (Ghiselli et al., 2000). $\mathrm{NaF}$ intoxicated groups showed significant alterations of hematological and biochemical indices with significantly depleted superoxide 
dismutase enzymes (SOD), decreased TAC and concomitant increase in TBARS and AOPP (Abou Anza and Salah Eldin, 2015). Similar results have been reported by Sarkar et al., (2014) they showed that the combined effect of reductions in antioxidant enzyme activity plus high levels of lipid peroxidation is associated with deleterious oxidative changes due to the accumulation of toxic products in F-treated rats. Therefore, enhancing endogenous antioxidant status by administrating exogenous compounds can provide an effective strategy to prevent and reverse NaF-induced toxicity (Wessam, 2013). Lopes et al., 2020 found that fluoride exposure decreased antioxidant capacity against peroxyl radicals (ACAP) levels at $10 \mathrm{mg} \mathrm{F} / \mathrm{L}$ and $50 \mathrm{mg} \mathrm{F} / \mathrm{L}$ groups compared to the control group.

Oral administration of $200 \mathrm{mg} / \mathrm{kg}$ b.w. of Z. spina-christi leaf extract either plain in STZ-diabetic rats for 28 days resulted in significant reduction in blood glucose level together with significant rise in serum insulin, C-peptide levels and TAC (Michel et al., 2011). Farag et al., (2015) concluded that kidney and liver injury due to cyclosporine can be significantly decreased by thymoquinone which resets the oxidant /antioxidant balance of the affected organ through scavenging the free radicals. Currently, the use of phytochemicals as a therapy in diseases related to oxidative stress has gained immense interest for their ability to quench free radicals and their capability to protect body tissues against oxidative stress (Nabavi et al., 2012). Guizani et al., (2013) stated that the mean TAC values among the control and Ziziphus spina-christi fruit groups were observed insignificant differences. Ziziphus spina-christi fruitadministration abrogated the Azoxymethane-induced TAC impairment. Amin and Ghoneim (2009) and Yossef et al., (2011) demonstrated that treatment of Ziziphus spina-christi fruit effectively protected against carbon tetrachlorideinduced liver damage by restoring the normal levels of lipid peroxidation and retaining the activities of endogenous anti-oxidants. Moreover, Mubaraki et al., (2017) found that Ziziphus spina-christi extract treatment markedly reinstated the levels of oxidative markers and enhanced antioxidant enzyme activities in mice with cerebral malaria. Dkhil et al., (2018) indicated that Ziziphus spina-christi fruit extract significantly and dose-dependently inhibited sepsis induced liver and spleen injury. These results suggest that it could provide a therapeutic agent for sepsis by inducing antinflammatory and antioxidant effects. High total polyphenols and flavonoids content of the R. alaternus extracts may be corroborated with the antioxidant and antigenotoxic activities (Ammar et al., 2007). The antilipid peroxidation activity of various extracts from R. alaternus, produced using the Soxhlet extraction method, was estimated by calculating the values of malondialdehyde (MDA) in cultured K562 human chronic myelogenous leukemia cells (Ammar et al., 2011). Rhamnus alaternus extracts containing total oligomer flavonoids (TOF) 
and ethyl acetate (EA) inhibited lipid peroxidation at a concentration comprised within $200-800 \mu \mathrm{g} / \mathrm{mL}$, the best activity being observed at the highest concentration $(800 \mu \mathrm{g} / \mathrm{mL})$. In this study, the IC50 values of TOF and EA extracts were determined at 196 and $265 \mu \mathrm{g} / \mathrm{mL}$, respectively. In comparison, a value of $17 \mu \mathrm{g} / \mathrm{mL}$ was obtained for vitamin $\mathrm{C}$, used as reference substance. Some flavonoids with antioxidant activity are described for Rhamnus species, like rutin, quercetin, kaempferol and rhamnocitrin (Bhouri et al., 2011 and Moussi et al., 2015). The ability to inhibit or prevent oxidative damage can be associated with the treatment and prevention diseases, especially those who own physiopathology associated with oxidative stress. Extracts of two Rhamnaceae family: Ziziphus jujuba Mill and Rhamnus alaternus L have antioxidant properties at different concentrations, with better activity for $R$. alaternus L leaves Chaouche et al., (2020). Chen et al., (2020) confirmed flavonoids and their glycosides were the major ingredients of $R$. prinoides and potentially responsible for its strong antioxidant and anti-inflammatory activities.

Table (5): Effect of Rhamnus (powder and extract), zinc and their cotreatment on oxidative status levels.

\begin{tabular}{|c|c|c|c|c|c|c|c|}
\hline Groups & $\begin{array}{l}\text { G (1): } \\
\text { Negative } \\
\text { control (N-) }\end{array}$ & \begin{tabular}{|l|}
$\mathbf{G}(2):$ \\
positive \\
control \\
$(\mathrm{N}+)$
\end{tabular} & $\begin{array}{l}\text { G(3): } \\
\text { zinc } \quad 20 \\
\text { mg/Kg } \\
\text { b.w./rats }\end{array}$ & $\begin{array}{l}\text { G(4): } 5 \% \\
\text { Rhamnus } \\
\text { powder }\end{array}$ & $\begin{array}{l}\text { G (5):5 ml } \\
\text { Rhamnus } \\
\text { extract }\end{array}$ & $\begin{array}{l}\text { G (6): } 5 \% \\
\text { Rhamnus } \\
\text { powder } \\
\text { +zinc }\end{array}$ & $\begin{array}{l}\text { G (7): } 5 \mathrm{ml} \\
\text { Rhamnus } \\
\text { extract } \\
\text { +zinc }\end{array}$ \\
\hline $\begin{array}{l}\text { TAS } \\
\text { (mmol Trolox } \\
\text { eq./L) }\end{array}$ & $\begin{array}{l}1.39 \pm \\
0.13 \mathrm{a}\end{array}$ & $\begin{array}{l}0.82 \pm \\
0.08 \mathrm{c}\end{array}$ & $\begin{array}{l}1.05 \pm \\
0.05 \mathrm{~b}\end{array}$ & $\begin{array}{l}0.94 \pm \\
0.03 \mathrm{~b}\end{array}$ & $\begin{array}{l}1.46 \pm \\
0.04 \mathrm{a}\end{array}$ & $\begin{array}{l}1.11 \\
\pm \\
4.13^{b}\end{array}$ & $\begin{array}{l}1.29 \\
\pm \\
4.61^{\mathrm{b}}\end{array}$ \\
\hline $\begin{array}{l}\text { TOS } \\
\text { (lmol } \\
\text { eq./L) }\end{array}$ & $\begin{array}{l}4.14 \pm \\
0.39 d\end{array}$ & $\begin{array}{l}9.17 \pm \\
0.38 \mathrm{a}\end{array}$ & $\begin{array}{l}7.10 \pm \\
0.21 \mathrm{~b}\end{array}$ & $\begin{array}{l}6.50 \pm \\
0.40 \mathrm{~b}\end{array}$ & $\begin{array}{l}5.53 \pm \\
0.40 b\end{array}$ & $\begin{array}{l}4.90 \pm \\
0.25 \mathrm{c}\end{array}$ & $\begin{array}{l}4.53 \pm \\
0.41 \mathrm{c}\end{array}$ \\
\hline
\end{tabular}

Mean values \pm SD in each column having different super $\operatorname{script}(a, b, c, d, e)$ are significant TAS: Total antioxidant status

TOS: Total oxidant status

\section{Effect of Rhamnus (powder and extract), zinc and their co-treatment} on oxidative status of the kidneys

Table 6 shows comparison of negative control group, NaF-treated group, $\mathrm{NaF}+\mathrm{Zn}$-treated group, $\mathrm{NaF}+$ rhamnus fruit (powder and extract)-treated groups and $\mathrm{NaF}+\mathrm{Zn}+$ rhamnus fruit (powder and extract)-treated groups, regarding to oxidative status of the kidneys. Significant decreases were noticed in NaFtreated group in comparison to the negative control group and all other treated groups with regard to total antioxidant status (TAS). The most significant amelioration was observed on the $\mathrm{NaF}+\mathrm{zn}+$ rhamnus fruit (powder and extract) -treated groups (G6 and G7). However, significant increases were noticed in 
NaF-treated group in comparison to the negative control group and all other treated groups with regard to total oxidant status (TOS). It could be noticed that there were no significant differences between negative control and $\mathrm{NaF}+\mathrm{Zn}$ treated group, $\mathrm{NaF}+$ rhamnus fruit (powder and extract) -treated groups and $\mathrm{NaF}+\mathrm{Zn}+$ rhamnus fruit (powder and extract)-treated groups. The observed $\mathrm{NaF}$ -induced TOS increment and TAS impairment represents an evidence of kidney oxidative stress. These results are consistent with the previous studies conducted that showed $\mathrm{NaF}$ at a dose of $50 \mathrm{mg} / \mathrm{l}$ increased excretion of fluoride in urine, promoted the activity of urine gamma-glutamyl transpeptidase (gamma-GT), inhibit the activities of serum glutathione peroxidase (GPX) and kidney superoxide dismutase (SOD), reduce kidney glutathione (GSH) content, and increased kidney malondialdehyde (MDA) (Yu et al., 2006). NaF at a dose of $50 \mathrm{mg} / \mathrm{l}$ also induced rat renal apoptosis, reduced the cell number of G2/M phases in the cell cycle, and decreased DNA relative content significantly. Selenium and zinc inhibited the effects of $\mathrm{NaF}$ on oxidative stress and apoptosis, promoted the cell number of G2/M phases in the cell cycle) اين (المرجع. Yu et al., (2002) suggested that NaF could induce apoptosis and change the cell cycle in rat renal cells and $\mathrm{Se}$ and $\mathrm{Zn}$ could antagonize apoptosis and the changes of cell cycle induced by $\mathrm{NaF}$.

\section{Table (6): Effect of Rhamnus (powder and extract), zinc and their co- treatment on oxidative status of the kidneys}

\begin{tabular}{|c|c|c|c|c|c|c|c|}
\hline Groups & $\begin{array}{l}\text { G(1): } \\
\text { Negative } \\
\text { control } \\
(\mathrm{N}-)\end{array}$ & \begin{tabular}{|l|}
$G(2):$ \\
positive \\
control \\
$(\mathrm{N}+)$
\end{tabular} & $\begin{array}{l}\text { G(3): } \\
\text { zinc 20 } \\
\text { mg/Kg } \\
\text { b.w./rats }\end{array}$ & $\begin{array}{l}\text { G(4): } 5 \% \\
\text { Rhamnus } \\
\text { powder }\end{array}$ & $\begin{array}{l}\text { G (5):5 ml } \\
\text { Rhamnus } \\
\text { extract }\end{array}$ & $\begin{array}{l}\text { G (6): } \\
5 \% \\
\text { Rhamnus } \\
\text { powder } \\
\text { +zinc }\end{array}$ & $\begin{array}{l}\text { G (7): } 5 \mathrm{ml} \\
\text { Rhamnus } \\
\text { extract } \\
\text { +zinc }\end{array}$ \\
\hline $\begin{array}{l}\text { kidney-TAS } \\
\text { (mmol Trolox } \\
\text { eq./L) }\end{array}$ & $\begin{array}{l}1.99 \pm \\
0.23 \mathrm{a}\end{array}$ & $\begin{array}{l}0.95 \pm \\
0.11 \mathrm{~b}\end{array}$ & $\begin{array}{l}1.03 \pm \\
0.09 \mathrm{ab}\end{array}$ & $\begin{array}{l}1.45 \pm \\
0.09 \mathrm{a}\end{array}$ & $\begin{array}{l}1.66 \pm \\
0.10 \mathrm{a}\end{array}$ & $\begin{array}{l}1.81 \\
\pm \\
4.13^{b}\end{array}$ & $\begin{array}{l}1.90 \\
\pm \\
4.61^{b}\end{array}$ \\
\hline $\begin{array}{l}\text { kidney-TOS } \\
\text { (lmol } \mathrm{H}^{2} \mathrm{O} 2 \\
\text { eq./L) }\end{array}$ & $\begin{array}{l}5.66 \pm \\
0.39 \mathrm{~b}\end{array}$ & $\begin{array}{l}8.37 \pm \\
0.38 \mathrm{a}\end{array}$ & $\begin{array}{l}5.62 \pm \\
0.21 \mathrm{~b}\end{array}$ & $\begin{array}{l}7.82 \pm \\
0.40 \mathrm{~b}\end{array}$ & $\begin{array}{l}6.68 \pm \\
0.40 \mathrm{~b}\end{array}$ & $\begin{array}{l}6.03 \pm \\
0.40 b\end{array}$ & $\begin{array}{l}5.98 \pm \\
0.41 b\end{array}$ \\
\hline
\end{tabular}

Mean values \pm SD in each column having different superscript $(a, b$,$) are significant$

TAS: Total antioxidant status

TOS: Total oxidant status

\section{Histopathological of the kidneys:-}

The histological alterations, including hypertrophy of glomerular tuft and thickening of parietal layer of Bowman's capsule of NaF-treated rats, whereas rhamnus (powder and extract), zinc and their co-treatment rats showed ameliorative effects and controlled the histological alterations. Kidneys have a 
prominent role in fluoride metabolism, where, $50-80 \%$ of fluoride is removed via urinary excretion (Xiong et al., 2007). Not surprisingly, the kidney is one of the major organs affected by fluoride intoxication, and numerous studies have established a close correlation between fluoride intake and renal injury. Hence, chronically intoxicated rats with sodium fluoride $(\mathrm{NaF})$ have displayed histological renal changes, interstitial edema, tubular destruction, and glomerular and medullary hyperemia. Hand in hand with the typical kidney pathology, fluoride-intoxicated rats showed an increased rate of reactive oxygen species (ROS) generation and lipid peroxidation (Kobayashi et al., 2009). Moreover, the histopathological changes in kidneys of chronic fluoride intoxication rats were mainly in the form of vacuolization and necrosis of tubules, atrophy of glomeruli, interstitial oedema, and interstitial nephritis. Investigators have explored the mechanism of renal lesion induced by excessive fluoride, consequently, collected numerous biological evidences, including oxidative stress (Xu et al., 2005), apoptosis (Xu et al.,2002), and signal transduction (Murao et al., 2000). In addition to, degeneration and necrosis of the tubular cells, glomeruli swelling as well as the renal tubular hyaline casts were observed in the experimental groups (Luo et al., 2017). Also, these histopathological lesions induced by fluoride are changed in a dose- and timedependent manner. In high doses of $\mathrm{NaF}$, the cytoachitecture of the kidneys exhibited increasing in the amounts of cloudy swellings, degeneration of tubular epithelia, tissue necrosis, extensive vacuolization in renal tubules, hypertrophy and atrophy of glomeruli, exudation, interstitial oedema, and interstitial nephritis. These changes in the kidneys result in impaired renal function in chronic fluoride intoxication (Shashi et al., 2020).

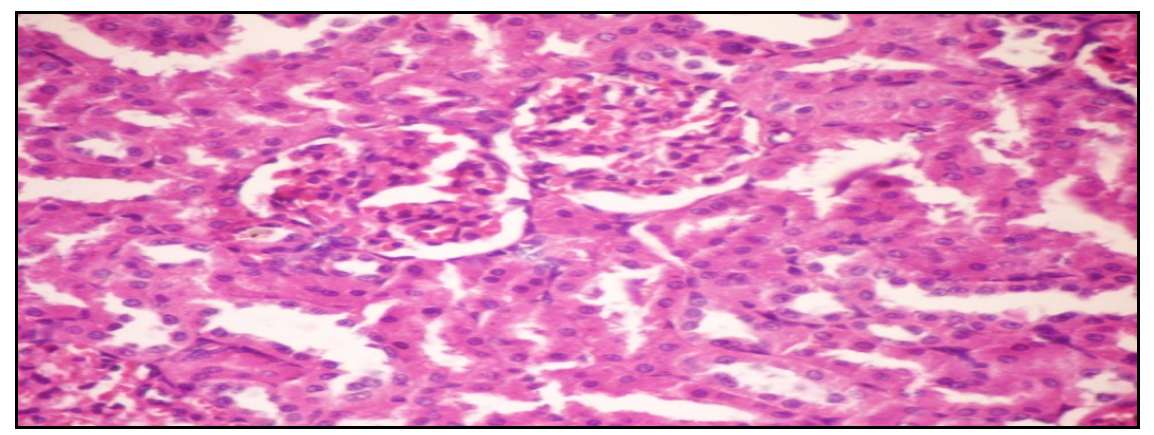

Photo (1): Kidney of rats from (normal control) healthy group showing the normal histological structure of renal parenchyma ( $H$ and $E$ X400) 


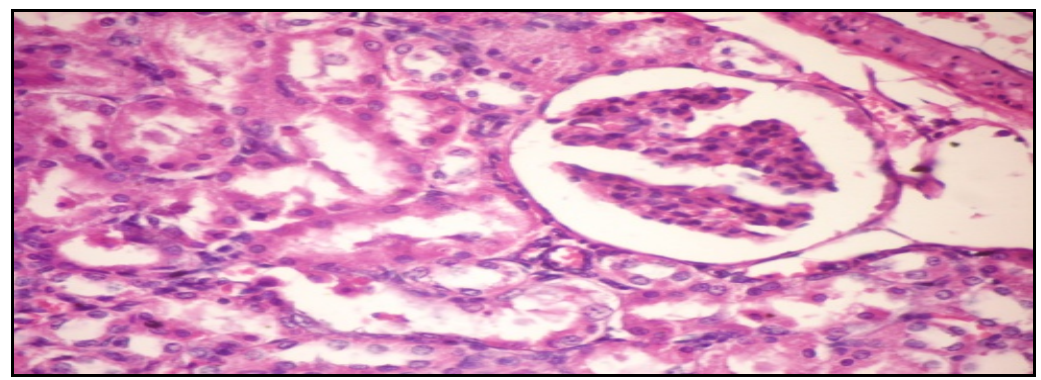

Photo (2): Kidney of rat from control (+ve) group showing hypertrophy of glomerular tuft and thickening of parietal layer of Bowman's capsule ( $H$ and $\mathbf{E}$ X400)

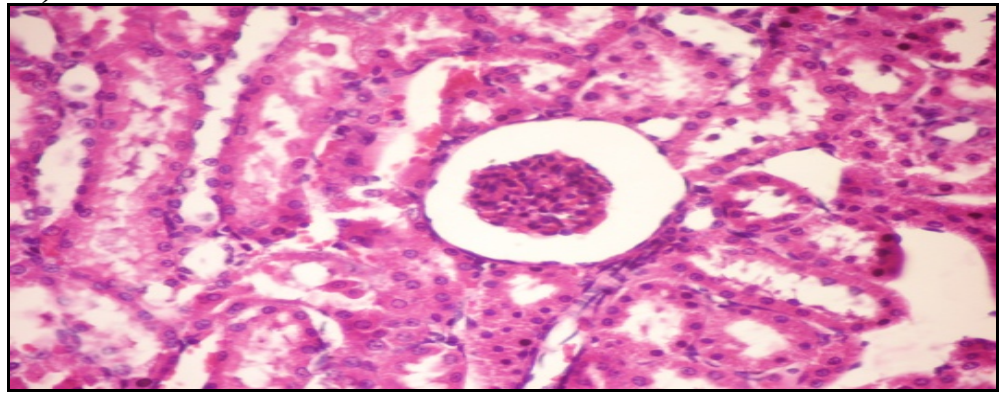

Photo (3): Kidney of rat from group 3 showing apparent normal renal parenchyma (H and E X 400).

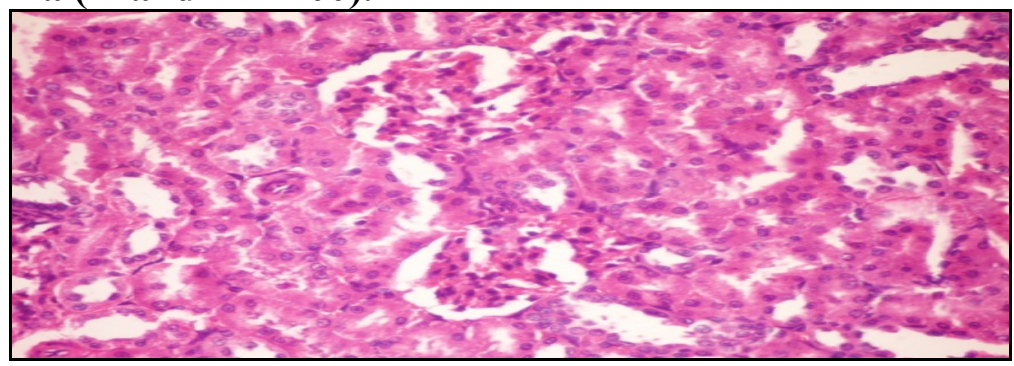

Photo (4): Kidney of rat from G4 showing congestion of renal blood vessels (H and $\mathrm{E} \times 200$ ).

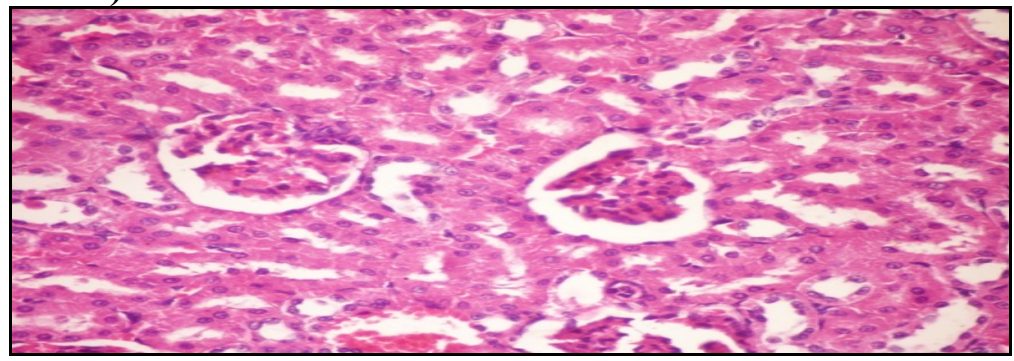

Photo (5): Kidney of rat from G5 showing revealed cystic dilatation of renal tubules with cellular cast in their lumen $(\mathrm{H}$ and $\mathrm{E} \times \mathbf{2 0 0})$. 


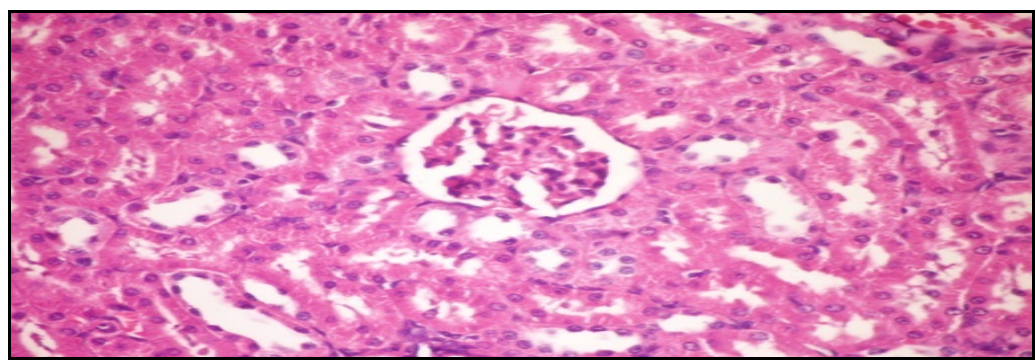

Photo (6): Kidney of rat from G6 showing cystic dilatation of renal tubules (H and E X 400).

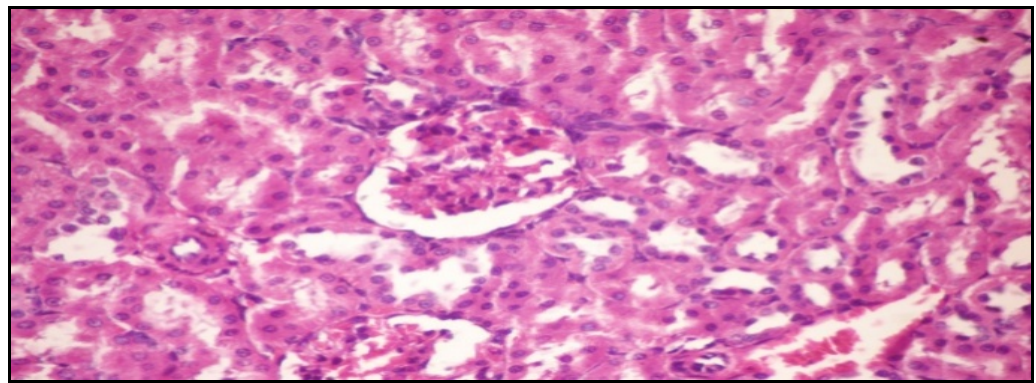

Photo (7): Kidney of rat from G7 showing no histopathological changes (H and $\mathbf{E}$ X400).

Conclusion: Administration of $\mathrm{NaF}$ caused biochemical and histopathological alternations and oxidative stress is a considered one of the main contributors to these changes. Treated $\mathrm{NaF}$ intoxicated rats with rhamnus fruits (powder and extract), zinc and their co-treatment caused ameliorated these effects.

Recommendations: Further studies to investigate the effect of $\mathrm{NaF}$ on other body organs and to explore the role of selected polyphenols compounds derivative from fruit which having antioxidant properties are recommended. 


\section{REFERENCES}

Abdel-Wahab, W. (2013). Protective effects of thymoquinone on sodium fluoride-induced hepatotoxicity and oxidative stress in rats. J Basic Appl. Zool., (66): 263-270.

Abou Anza, R.E. and Salah Eldin, H.M.(2015). Mitigation of Fluoride Toxicity by the Use of Thymoquinone in Adult Male Albino Rat. Ain Shams Journal of Forensic Medicine and Clinical Toxicology, 24: 1-10.

Agalakova, N. and Gusev, G. (2013). Excessive fluoride consumption leads to accelerated death of erythrocytes and anemia in rats. Biol Trace Elem Res., 153(1-3):340-9.

Al-Harbi, M. Hamza, R. and Afaf, A. (2014). Hyperlipidemic and oxidative stress effects of sodium fluoride and the ameliorative role of selenium and curcumin in male mice. Journal of Chemical and Pharmaceutical Research, 6(4):984-998.

Allian, C. C.; Poon, L.S.; Chan, C. S. and Richmond, W. (1974). Enzymatic determination of total serum cholesterol. Clin. Chem.; 20: 470.

Almeer, R. S.; Mahmoud, S.M.; Amin, H. K. and Abdel Moneim, A.E. (2018). Ziziphus spina-christi fruit extract suppresses oxidative stress and p38 MAPK expression in ulcerative colitis in rats via induction of Nrf2 and HO-1 expression. Food and Chemical Toxicology 115: 49-62.

Al-Olayan, E.; El-Khadragy, M.; Metwally, D. and Abdel Moneim, A. (2014). Protective efects of pomegranate (Punica granatum) juice on testes against carbon tetrachloride intoxication in rats. BMC Complement Altern Med., 14:164.

Al-Sabaawy, H.B. and Al-Kaisie, B. I. (2020). Effects of Sub Lethal Concentrations of Sodium Fluoride on Sperm Activity and on the level of Sex Hormones of Adult Male Albino Rats. The Iraqi Journal of Veterinary Medicine, 44 (2): 92-98.

Amin, A. and Ghoneim, D. (2009) Zizyphus spina-christi protects against carbon tetrachloride-induced liver fibrosis in rats. Food Chem Toxicol., 47:2111-2119. https://doi.org/10.1016/j.fct.2009.05.038

Ammar, R. B.; Miyamoto, T. and Chekir-ghedira, L. (2018). Isolation and identification of new anthraquinones from Rhamnus alaternus L and evaluation of their free radical scavenging activity. Nat. Prod. Res., 6419: 1-7. 
Ammar, R.B.; Bouhlel, I.; Kita Valenti, K.; Sghaier, M.B.; Kilani, S.; Mariotte, A.M.; Dijoux-Franca, M.G.; Laporte, F.; Kamel Ghedira, K. and Chekir-Ghedira, L. (2007) .Transcriptional response of genes involved in cell defense system in human cells stressed by $\mathrm{H}_{2} \mathrm{O}_{2}$ and pre-treated with (Tunisian) Rhamnus alaternus extracts: Combination with polyphenolic compounds and classic in vitro assays. Chemico-Biological Interactions, 168: 171-183.

Ammar, R.B.; Neffati, A.; Skandrani, I.; Ben Sghaier, M.; Bhouri, W.; Ghedira, K. and Chekir-Ghedira, L. (2011). Anti-lipid peroxidation and induction of apoptosis in the erythroleukaemic cell line K562 by extracts from (Tunisian) Rhamnus alaternus L. (Rhamnaceae). Nat. Prod. Res., 25(11): 1047-1058.

Atmaca, N.; Atmaca, H.; Kanici, A. and Anteplioglu, A. (2014). Protective effect of resveratrol on sodium fluoride-induced oxidativestress, hepatotoxicity and neurotoxicity in rats. Food and Chemical Toxicology, 70: 191-197.

ATSDR (Agency for Toxic Substances and Disease Registry) (2003). Toxicological Profile for Fluorides, Hydrogen Fluoride, and Fluorine. Public Health Service, US Department of Health and Human Services, Atlanta, Georgia.

Bao, L.; Hu, L.; Zhang, Y. and Wang, Y. (2016). Hypolipidemic effects of flavonoids extracted from Lomatogonium rotatum. Exp. Ther. Med., 11 (4): 1417-1424.

Bartles, H.; Bohmer, M. and Heirli, C. (1972): Colorimetric kinetic method of determination of creatinine. J. Clin. Chem. Acta., (37): 193-197.

Bergmeyer, H. U. and Horder, M. (1980). Methods for the measurement of catalytic concentration of enzymes. J. Clin. Chem. Clin. Biochem. 18: 521-534.

Bhouri, B.; Ben sghaier, M.; Kilani, S. and Chekir-Ghedira, S. (2011). Evaluation of antioxidant and antigenotoxic activity of two flavonoids from Rhamnus alaternus L. (Rhamnaceae): Kaempferol 3-O- $\beta$-isorhamninoside and rhamnocitrin 3-O- $\beta$-isorhamninoside. Food and chemical toxicology, 49(5):1167-1173.

Bhouri, W.; Boubaker, J. and Kilani, S. (2012). Flavonoids from Rhamnus alaternus L. (Rhamnaceae): Kaempferol 3-O- $\beta$-isorhamninoside and rhamnocitrin 3-O- $\beta$ isorhamninoside protect against DNA damage in human lymphoblastoid cell and enhance antioxidant activity. S. Afr. J. Bot., 80: 57-62. 
Birkner, E.; Grucka-Mamczar, E.; Żwirska-Korczala, K.; Zalejska-Fiolka, J.; Stawiarska-Pięta, B.; Kasperczyk, S. and Kasperczyk, A. (2006). Influence of sodium fluoride and caffeine on the kidney function and freeradical processes in that organ in adult rats. Biol Trace Elem Res., 109:35-47.

Blaszczyk, I.; Birkner, E. and Kasperczyk, S. (2011). Influence of methionine on toxicity of fluoride in the liver of rats. Biol. Trace. Elem. Res. 139:325- 331.

Boussahel, S.; Dahamna, S.; Ruberto, G.; Siracusa, L. and Harzallah, D. (2013). Phytochemical study and antioxidant activities of leaves extracts from Rhamnus alaternus L. Pharmacogn. Commun., 3: 46-53.

Bukar, M.; Kyari, M.Z.; Gwaski, P.A.; Gudusu, M.; Kuburi, F.S. and Abadam, Y.I. (2015). Evaluation of phytochemical and potential antibacterial activity of Ziziphyus spina-christi L. against some medically important pathogenic bacteria obtained from University of Maiduguri Teaching Hospital, Maiduguri, Borno State - Nigeria. Journal of Pharmacognosy and Phytochemistry 3:98-101

Campbell, M.; Zhao, W.; Fathi, R.; Mihreteab, M. and Gilbert, E.S. (2019). Rhamnus prinoides (gesho): A source of diverse anti-biofilm activity. Journal of Ethnopharmacology, 241:111955.

Chang, C.J.; Tzeng, T.-F.; Liou, S.-S.; Chang, Y.-S. and Liu, I.-M. (2011). Kaempferol regulates the lipid-profile in high-fat diet-fed rats through an increase in hepatic PPAR $\alpha$ levels. Planta Med., 77 (17): 1876-1882.

Chaouche, T.M.; Haddouchi, F.; Boudjemai, O. and Ghellai, I. (2020). Antioxidant and hemolytic activity of Ziziphus jujuba Mill and Rhamnus alaternus L (Rhamnaceae) extracts from Algeria. Bulletin de la Société Royale des Sciences de Liège., 89: 1 - 14.

Chapman, D.G.; Gastilla, R. and Campbell, T.A. (1950). Evaluation of protein in food. I. A. Method for the determination of protein efficiency ratio. Can. J. Biochem. Physio. I (37) 679-686.

Chen, G. L.; Mutie, F. M.; Xu, Y.B.; Saleri , F. D.; Hu, G.W. and MingQuan Guo, M.Q. (2020). Antioxidant, Anti-inflammatory Activities and Polyphenol Profile of Rhamnus prinoides. Pharmaceuticals, 13: 55.

Chen, G.; Wu, J.; Li, N. and Guo, M. (2018). "Screening for antiproliferative and anti-inflammatory components from Rhamnus davurica Pall. Using bio- 
affinity ultrafiltration with multiple drug targets". Analytical and Bioanalytical Chemistry, 410 (15): 3587-3595.

Chinoy, N. J.; Sequeria, E. and Narayana, M.V. (1991). Effects of vitamin C and calcium on the reversibility of fluoride induced alterations in spermatozoan of rabbit. Fluoride, 24(1): 29-39.

Chlubek, D. (2003). Fluoride and oxidative stress. Fluoride, 36:217-228.

Comlekcioglu, N.; Aygan, A.; Kutlu, M. and Kocabas, Y.Z. (2017). Antimicrobial activities of some natural dyes and dyed wool yarn. Iran. J. Chem. Chem. Eng. Research Note, 36.

Cotruvo, J. A. (2017). WHO Guidelines for Drinking Water Quality: First Addendum to the Fourth Edition. J Am Water Works Asso.,1(109):44-51.

Cuoco, G.; Mathe, C. and Vieillescazes, C. (2014). Liquid chromatographic analysis of flavonol compounds in green fruits of three Rhamnus species used in Stil de grain. Microchemical Journal 115:130-137.

Dkhil, M.A.; Al-Quraishy, S. and Moneim, A.E.A. (2018). Ziziphus spinachristi leaf extract pretreatment inhibits liver and spleen injury in a mouse model of sepsis via antioxidant and anti-inflammatory effects. Inflammopharmacolog, 26: 779-791.

Dote, T.; Kono, K.; Usuda, K.; Nishiura, H. and Tagawa, T. (2000). Acute renal damage dose response in rats to intravenous infusion of sodium fluoride. Fluoride 33:210-217.

Erel, O. (2004). A novel automated direct measurement method for total antioxidant capacity using a new generation, more stable ABTS radical cation. Clin. Biochem. 37: 277-285.

Erel, O. (2005). A new automated colorimetric method for measuring total oxidant status. Clin. Biochem. 38: 1103-1111.

Fallahzadeh, R. A.; Miri, M.; Taghavi, M,; Gholizadeh, A.; Anbarani, R. and Hosseini-Bandegharaei, A. (2018). Spatial variation and probabilistic risk assessment of exposure to fluoride in drinking water. Food and Chem Toxicol., 113:314-321.

Farag, M.; Ahmed, G.; Shehata, R. and Kazem, A. (2015): Thymoquinone improves the kidney and liver changes induced by chronic cyclosporine A treatment and acute renal ischaemia/reperfusion in rats. Journal of Pharmacy and Pharmacology; DOI: 10.1111/jphp.12363. 
Fatehi-Hassanabad, Z.; Chan, C.B. and Furman, B.L. (2010). Reactive oxygen species and endothelial function in diabetes. Eur J Pharmacol.,636:817.

Fossati, P. and Prencipel, L. (1982). Determination of triglycerides, Bicon Diagnostics, made in Germany. Clinical Chemistry, 28: 2077-2078.

Frankel, S. and Reitman, S. (1963). Clinical Laboratory's Methods. The. C.V. Mosbye Company, 1102.

Garcia-Montalvo, E.; Reyes-Perez, H. and Del Razo, L. (2009). Fluoride exposure impairs glucose tolerance via decreased insulin expression and oxidative stress. Toxicology, 263: 75-83.

Ghaffari, K.; Ahmadi, R.; Behrooz Saberi, B. and Pooria Moulavi, P. (2021). Anti-proliferative effects of Ziziphus spina-christi and Phlomis russeliana leaf extracts on HEK293 and MCF-7 Cell Lines and Evaluation of Bax and Bcl-2 Genes Expression Level in MCF-7 Cells. Asian Pac J Cancer Prev., 22(S1):81-87.

Ghiselli, A.; Serafini, M. and Natella, F. (2000). Total antioxidant capacity as a tool to assess redox status: Critical view and experimental data. Free Radical Biology and Medicine, 29(11): 1106-1114.

Ghosh, D.; Das Sarkar, S.; Maity, R.; Jana, D. and Das, U.B. (2002). Testicular toxicity in sodium fluoride treated rats: association with oxidative stress. Reprod Toxicol.,16:385-90. PMID: 12220599.

Ghosh, J.; Das, J.; Manna, P. and Sil, P, (2008). Cytoprotective effect of arjunolic acid in response to sodium fluoride mediated oxidative stress and cell death via necrotic pathway. Toxicol. In Vitro., 22:1918-1926.

Gordon, T. and Amer, M. (1977). Determination of HDL. J. Med.; 62 : 707.

Goupy, P.; hugues, M.; Boivin, P. and Amiot, J., (1999). Phenolic compounds. Official methods(ISO). J.Sci. Food Agric., 79:1625-1634.

Grucka-Mamczar, E.; Birkner, E.; Polaniak, R.; Stawiarska-Pięta, B.; Ceglowska, A. and Gajda, M. (2003). Disturbances of kidney function in young rats after chronic exposure to $\mathrm{NaF}$ contained in drinking water. Ann Acad Med Siles, 54-55: 9- 14.

Guizani, N.; Waly, M.I.; Singh, V. and Rahman, M.S. (2013). Nabag (Zizyphus spina-christi) extract prevents aberrant crypt foci development in 
colons of azoxymethane-treated rats by abrogating oxidative stress and inducing apoptosis. Asian Pac. J. Cancer Prev. 14, 5031-5035.

Haisman, P. and Muller, B.R. (1977). Quantitative enzymatic colorimetric determination of uric acid in serum. Clin. Chem., 26:227.

Hemeg , H.A.; Moussa, I.M.; Ibrahim, S.; Dawoud, T.M.; Alhaji, J.H.; Mubarak, A.S.; Kabli, S.A.; Alsubki, R.A.; Tawfik, A.M.; and Marouf, S.A. (2020). Antimicrobial effect of different herbal plant extracts against different microbial population. Saudi Journal of Biological Sciences 27: 32213227.

Huang, S. W. and Frankel, E.N. (1997). Antioxidant activity of tea catechins in different lipid systems. J. Agric. Food Chem., 45: 3033-3038.

Iheka C. U.; Onyegeme-Okerenta, B. M. and Anacletus F. C. (2015). Impact of Fluoride Toxicity and Ameliorative Effects of Some Antioxidants on Selected Biochemical Indices of Male Rats. AASCIT Journal of Health, 2(6): 87-92.

Inkiewicz, I. and Krechniak, J. (2003). Fluoride content in soft tissues and urine of rats exposed to sodium fluoride in drinking water. Fluoride 36:263266.

Jafarian, A.; Zolfaghari, B. and Shirani, K. (2014). Cytotoxicity of different extracts of arial parts of Ziziphus spina-christi on Hela and MDA-MB-468 tumor cells. Adv. Biomed. Res., 3: 38.

Kadioglu，O. Jacob，S.; Bohnert ，S.; Na，J.; Saeed， M.E.M. Khalid, H.; Merfort, I.; Thines, E. Pommerening, T. and Efferth, T. (2016). Evaluating ancient Egyptian prescriptions today: anti-infammatory activity of Ziziphus spina-christi. Phytomedicine, 23:293-306 (S0944-7113(16)

Kanbur, M.; Eraslan, G.; Silici, S. and Karabacak, M. (2009): Effects of sodium fluoride exposure on some biochemical parameters in mice: Evaluation of the ameliorative effect of royal jelly applications on these parameters. Food Chem Toxicol; 47:1184-1189.

Kelly, F.J. (2010). Oxidative Stress : Its Role in Air Pollution and Adverse Health Effects POLLUTION STRESS : AND ITS ROLE ADVERSE IN AIR HEALTH EFFECTS. Occup. Environ. Med., 60:, 612-616.

Khamis, A.A.; Salama, A.F.; Kenawy, M.E. and Mohamed, T.M. (2017). Regulation of hepatic hydroxy methyl glutarate-CoA reductase for controlling hypercholesterolemia in rats, Biomed. Pharmacother. 95: 1242-1250. 
Khudair, K. and Aldabaj, A. (2014). Effect of High Concentration of Sodium Fluoride on Serum Lipid Profile of Male Rabbits: Hypolipidemic Effect of Grape Seed Oil. Online International Interdisciplinary Research Journal; \{BiMonthly\}, ISSN2249-9598, Volume-IV, Special Issue.

Kim, H. O.; Shin, K. R.; Jang, B. and Kim, Y.C. (2020). Action mechanism of anti-wrinkle efect of Rhamnus yoshinoi methanol extract in human dermal fbroblast and keratinocyte cell lines. Toxicol Res. 36:69-77.

Kumar, N. K.; Nageshwar, M. and Pratap Reddy, K. (2020). Protective Effect of Curcumin on Hippocampal and Behavior Changes in Rats Exposed to Fluoride During Pre- and Post-natal Period. Basic and Clinical Neuroscience, 11(3), 289-300.

Kobayashi, C. A. N.; Leite, A. L.; Silva, T. L.; Santos, L. D.; Nogueira, F. C. S.; Oliveira, R. C. Palma, M. S.; Domont, G. B. and Buzalaf, M.A.R. (2009). Proteomic analysis of kidney in rats chronically exposed to fluoride. Chem-Biol Interact., 180:305-311.

Kuang, W.; Zhang, X. and Lan, Z. (2017). Flavonoids extracted from Linaria vulgaris protect against hyperlipidemia and hepatic steatosis induced by western-type diet in mice, Arch. Pharm. Res.: 1-9.

Lee, R. D. and Nieman, D. C. (1996). Nutritional assessment. 2 nd Ed., Mosby, Missoun, USA.

Liang, N. and Kitts, D.D. (2015). Role of chlorogenic acids in controlling oxidative and infammatory stress conditions. Nutrients, 8(1): 16 https:// doi.org/10.3390/nu8010016.

Lopes, G.O.; Ferreira, M.K.M.; Davis, L.; Bittencourt, L.O.; Aragão, W.A.B.; Dionizio, A.; Buzalaf, M.A.R.; Crespo-Lopez, M.E.; Maia, C.S.F. and Lima, R.R.(2020). Effects of Fluoride Long-Term Exposure over the Cerebellum: Global Proteomic Profile, Oxidative Biochemistry, Cell Density, and Motor Behavior Evaluation. Int. J. Mol. Sci., 21: 7297.

Luo,Q.; Cui, H.; Deng, H.; Kuang, P.; Liu, H.; Lu, Y.; Fang, J.; Zuo, Z.; Deng, J.; Li, Y.; Wang, X. and Zhao, L. (2017). Histopathological findings of renal tissue induced by oxidative stress due to different concentrations of fluoride. Oncotarget, 8(31): 50430-50446.

Ma, Y.; Jiang, C.; Yao, N.; Li, Y.; Wang, Q.; Fang, S.; Shang, X.; Zhao, M.; Che, C. and Ni, Y. (2015). Antihyperlipidemic effect of Cyclocarya 
paliurus (Batal.) Iljinskaja extract and inhibition of apolipoprotein B48 overproduction in hyperlipidemic mice, J. Ethnopharmacol, 166: 286-296.

Madhusudhan, N.; Basha, P. M.; Rai, P.; Ahmed, F. and Prasad, G. R. (2010). Effect of maternal fluoride exposure on developing CNS of rats: Protective role of Aloe vera, Curcuma longa and Ocimum sanctum. Indian Journal Experimental Biology, 48(8): 830-6.

Malin, A and Christine, T (2015). Exposure to fluoridated water and attention deficit hyperactivity disorder prevalence among children and adolescents in United States: An ecological association. Environmental Health; 14(17): doi:10.1186/s12940-015-003-1.

Marzouk, M.S.; El-Toumy, S.A.A.; Merfort, I. and Nawwar, M.A.M. (1999). Polyphenolic metabolites of Rhamnus disperma. Phytochemistry, 52.

Michel, C.G.; Nesseem, D.I. and Ismail, M. F. (2011). Anti-diabetic activity and stability study of the formulated leaf extract of Zizyphus spina-christi (L.) Willd with the influence of seasonal variation. J Ethnopharmacol 133:5362 (pii:S0378-8741(10)00639-2)

Montezano, A. C. and Touyz, R. M. (2012). Molecular mechanisms of hypertension-reactive oxygen species and antioxidants: a basic science update for the clinician. Can J Cardiol., 28:288-295.

Montoro, P.; Braca, A.; Pizza, C. and Tommasi, N. (2005). Structure antioxidant activity relationships of flavonoids isolated from different plant species. Food Chem., 92: 349-355.

Moreira, T. F. Deoliveira, D. M. and Arruda, M. F. (2013). "Lipid peroxidation inhibition by ethanolic extract and fractions from Rhamnus sphaerosperma var. pubescens (Reissek) M.C. Johnst. (Rhamnaceae)". International Journal of Phytomedicine, 5 (2): 136-140.

Moreira, T.F.; Sorbo, J.M; Souza, F.D.O.; Fernandes, B.C.; Ocampos, F.M.M.; de Oliveira, D.M.S.; Arcaro, C.A.; Assis, R.P.; Barison, A.; Migue, O.G; Baviera, A.M.; Soares, C.P. and Brunetti, I. L. (2018). Emodin, Physcion, and Crude Extract of Rhamnus sphaerosperma var. pubescens Induce Mixed Cell Death, Increase in Oxidative Stress, DNA Damage, and Inhibition of AKT in Cervical and Oral Squamous Carcinoma Cell Lines. Oxidative Medicine and Cellular Longevity, ID 2390234, 18 pages https://doi.org/10.1155/2018/2390234. 
Moussi, K. Nayak, B.; Perkins, L. B.; Dahmoune, F.; Madani, K. and Chibane, M. (2015). HPLC-DAD profile of phenolic compounds and antioxidant activity of leaves extract of Rhamnus alaternus L. Industrial Crops and Products, 74: 858-866.

Mubaraki, M.A.; Hafiz, T.A.; Al-Quraishy, S. and, Dkhil, M.A. (2017) Oxidative stress and genes regulation of cerebral malaria upon Zizyphus spinachristi treatment in a murine model. Microb Pathog 107:6974. https://doi.org/10.1016/j.micpath.2017.03.017

Mulvihill, E.E.; Assini, J.M.; Lee, J.K.; Allister, E.M.; Sutherland, B.G.; Koppes, J.B.; Sawyez, C.G.; Edwards, J.Y.; Telford, D.E. and Charbonneau, A. (2011). Nobiletin attenuates VLDL overproduction, dyslipidemia, and atherosclerosis in mice with diet-induced insulin resistance. Diabetes, 60 (5): 1446-1457.

Murao, H.; Sakagami, N.; Iguchi, T.; Murakami, T. and Suketa, Y. (2000). Sodium fluoride increase intracellular calcium in rat renal epithe-lial cell line NRK-52E. Biol. Pharm. Bull., 23 (5): 581-584.

Nabavi, S. M,; Nabavi, S. F.; Eslami, S. and Moghaddam, A.H. (2012). In vivo protective effects of quercetin against sodium fluoride induced oxidative stress in the hepatic tissue. Food Chem., 132: 931-935.

Nabavi, S.F.; Habtemariam, S.; Sureda, A.; Moghaddam, A. H.; Daglia, M. and Nabavi, S.M. (2013). In vivo protective effects of gallic acid isolated from Peltiphyllum Peltatum against sodium fluoride-induced oxidative stress in rat erythrocytes. Inhibition of oxidative stress by gallic acid in vivo. Arh Hig Rada Toksikol, 64:553-559.

Nageshwar, M.; Kirankumar, N.; Rajkiran R. B.; Chandrashakar, R. N.; and Reddy, K. P. (2017). Quercetin treatment against NaFinduced oxidative stress related neuronal and learning changes in developing rats. Journal of King Saud University-Science, 29(2), 221- 229.

Natalia, I. and Gennadii P. (2012). Molecular mechanisms of cytotoxicity and apoptosis induced by inorganic fluoride. ISRN Cell Biology; Article ID 403835.

NRC (National Research Council) (2006). Fluoride in Drinking-Water. A scientific review of EPA's standards, Washington. 
NRC, (1995). National Research Council: Nutrient Requirements of Laboratory Animals. Fourth Revised Edition, National Academy Press. Washington, DC: 29-30.

Paget, G. E. and Barnes, J. M. (1964): Inter species dosages conversion scheme in evaluation of results and quantitative application in different species toxicity test. Academic Press London and NY: 135-165.

Park, K.Y.; Jung, G.O.; Lee, K.T.; Choi, J.; Choi, M.Y.; Kim, G.T.; Jung, H.J. and Park, H.J. (2004). Antimutagenic activity of flavonoids from the heartwood of Rhus verniciflua. J. Ethnopharmacol, 90: 73-79.

Pendrys D (2001). Fluoride ingestion and oral health. Nutrition; 17(11-12): 979-980.

Pratt, D. and Kaplan, M. (2005). Evaluation of liver function. In: Harrison's principles of internal medicine. Braunwald E, Fauci AS, Kasper DL, Hauser SL, Longo DL, Jameson JL (eds.), 16th ed., McGraw-Hill, New York, pp: 1711171.

Reitman, S. and S. Frankel, (1957). Determination of glutamate pyruvat transaminase and glutamate oxaloacetate transaminase. Am. J. Clin. Path., 28(1): 56-63.

Rocchetti, G.; Miras-Moreno, M.B.; Zengin, G.; Senkardes, I.; Sadeer, N. B.; Mahomoodally, M. F. and Lucini, L. (2019). UHPLC-QTOF-MS phytochemical profiling and in vitro biological properties of Rhamnus petiolaris (Rhamnaceae). Industrial Crops \& Products 142: 111856.

Sahay, M. (1986). Histopathological And Cytogenetic Effect Of Aflatoxins In Mammal. Ph.D Thesis: T. M Bhagalpur Univ. Bhagalpur.

Saied, A.S.; Gebauer, J.; Hammer, K. and Buerkert, A. (2008). Ziziphus spina-christi (L.) Willd.: a multipurpose fruit tree. Genet Resour Crop Evol., 55:929-937.

Sarkar, C.; Das, N.; Pal, S. and Dinda, B. (2014). Oxidative stress induced alteration of protein and nucleic acid metabolism in fluoride intoxicated rat brain. Protection by $3 \alpha$-hydroxy oleanolic acid isolated from Neonatis Wightiana. IJPSR; 5 (7):3047-3066.

Sashi, A.; Aihgh, J. P. and Thapar, S.P. (2002). Toxic effect of fluoride on rabbit kidney. Fluoride 35:38-50. 
Shahat, A.A.; Pieters, L.; Apers, S.; Nazeif, N.M.; Abdel-Azim, N.S.; Bergh, D.V. and Vlienk, A.J. (2001). Chemical and biological investigations on Zizyphus spina-christi L. Phytother. Res., 15: 593-597.

Shashi, A. and Thapar, S. (2001). Histopathology of fluoride-induced hepatotoxicity in rabbits. Fluoride, 34(1):34-42.

Shashi, A.; Singh, J.P. and Thapar, S.P. (2020). Toxic effects of fluoride on rabbit kidney. Fluoride 35(1):38-50.

Shen , X. ; Tang ,Y. ; Yang, R.; Yu, L. ; Fang, T. and Duan , (2009). The protective effect of Zizyphus jujube fruit on carbon tetrachloride-induced hepatic injury in mice by anti-oxidative activities. Journal of Ethnopharmacology, 122: 555-560.

Snedecor, G.W. and Cochran, W.G. (1967). Statistical Methods. 7th Ed., The Lowa State University Press. Ames, Lowa, U.S.A.

Storz, P. (2006). Reactive oxygen species-mediated mitochondria-tonucleus signaling: a key to aging and radical-caused diseases. Sci STKE., 332:re3. doi: 10.1126/stke.3322006re3.

Strunecka, A. and Strunecky, O. (2020). Mechanisms of luoride toxicity: from enzymes to underlying integrative networks. Appl Sci.,10(20):7100.

Tacherfiout, M.; Petrov, P.D.; Mattonai, M.; Ribechini, E.; Joan Ribot, J.; M. Luisa Bonet, L. and Khettal, B. (2018). Antihyperlipidemic effect of a Rhamnus alaternus leaf extract in Tritoninduced hyperlipidemic rats and human HepG2 cells. Biomedicine \& Pharmacotherapy, 101: 501-509.

Tessema, Z. and Molla, Y. (2021). Evaluation of the wound healing activity of the crude extract of root bark of Brucea antidysentrica, the leaves of Dodonaea angustifolia and Rhamnus prinoides in mice. Heliyon 7 (1): e05901.

Tripathi, M.; Pandey, M.B.; Jha, R.N.; Pandey, V.B.; Tripathi, P.N. and Singh, J.P. (2001). Cyclopeptide alkaloids from Zizyphus jujuba. Fitoterapia 72, 507-510.

Vani, M.L. and Reddy, K. P. (2000). Effects of fluoride accumulation on some enzymes of brain and gastrocnemius muscle of mice. Fluoride, 33:17-26.

Vassault, A. (1983). Methods of enzymatic analysis, enzymes1. Oxidoreductases, transferases Vol. III. Verlag Chemie, Basel, 118-126.

Vaya, J.; Mohmod, S.; Goldblum, A.; Aviram, M.; Volkavor, N.; Shaalam, A.; Musa, R. and Tamir, S. (2003). Inhibition of LDL oxidation by flavonoids 
in relation to their structure and calculated enthalpy. Phytochemistry, 62: 8999.

Wang, W. and Li, Y. (2002). Environmental epidemiology of fluorine and its effects on health. Soil, water and Environmental Science, 11(4): 383-387.

Wessam, M. (2013). Protective effect of thymoquinone on sodium fluorideinduced hepatotoxicity and oxidative stress in rats. The Journal of Basic and Applied Zoology; 66(5):263-270.

Xiong, X.; Liu, J. and He, W. (2007). Dose effect relationship between drinking water fluoride levels and damage to liver and kidney functions in children. Environ Res.,103:112-116.

Xu, H.; Sun, B. and Li, G.S. (2002). The mechanism of nephric apop-tosis induced by chronic fluorosis. Chin. J. Endemicol., 21 (4):251-253.

Xu, H.; Zhang, J. M.; Chang, M. and Li, G.S. (2005). Expression of Bcl-2on the oxidative stress of renal tubular cells treated by NaF. Chin.J. Endemiol., 24 (1): 17-20.

Yossef, H. E.; Khedr, A.A. and Mahran, M. Z. (2011). Hepatoprotective activity and antioxidant effects of El Nabka (Zizyphus spina-christi) fruits on rats hepatotoxicity induced by carbon tetrachloride. Nature and Science, 9 (2).

Yu, R.; Xia, T.; Wang, A. and Chen, X. (2002). Effects of selenium and zinc on rat renal apoptosis and change of cell cycle induced by fluoride. Chinese Journal of Preventive Medicine, 36(4):219-221.

Yu, R.A.; Xia, T.; Wang, A.G. and Chen, X.M. (2006). Effects of selenium and zinc on renal oxidative stress and apoptosis induced by fluoride in rats. Biomedical and EnvironmentalSciences,19(6):439-444.

Zeouk, I.; Ouedrhiri, W.; Jiménez, I.A.; Lorenzo-Morales, J.; Bazzocchi, I.L. and Bekhti, K . (2020). Intra-combined antioxidant activity and chemical characterization of three fractions from Rhamnus alaternus extract: Mixture design. Industrial Crops \& Products, 144: 112054. 


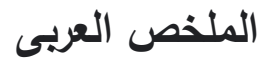

التأثيرات التحسينية لقاكهة النبق على الإجهاد التأكسدي الناجم عن فلوريد الصوديوم

\section{في القئران}

ينتشر الفلوريد على نطاق واسع في الطبيعة بأثكال عديدة وينم استخدام مركباته على نطاق

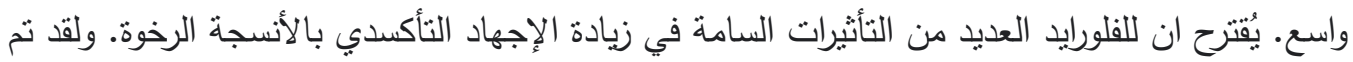

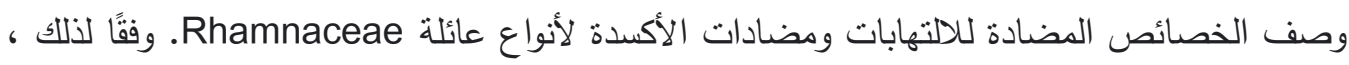

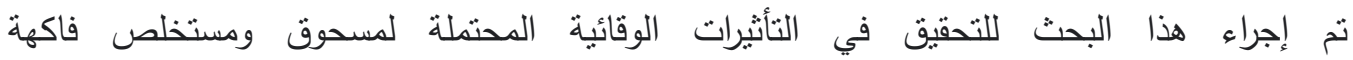

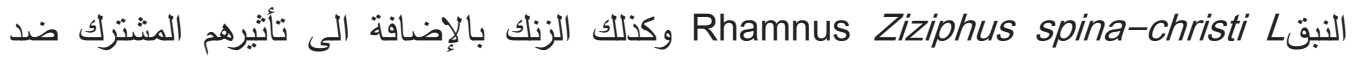

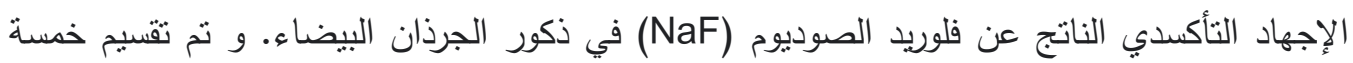

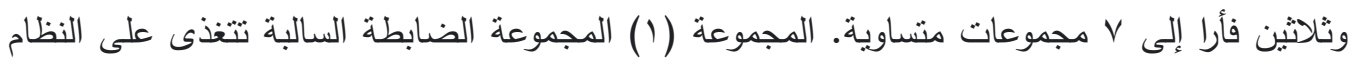

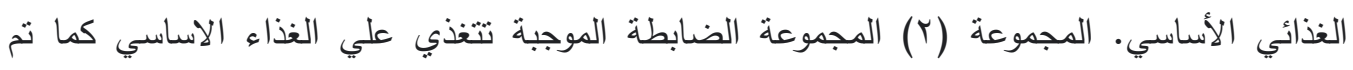

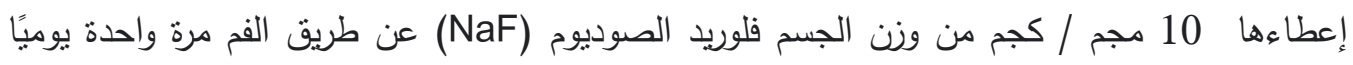

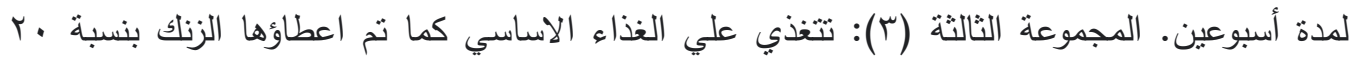

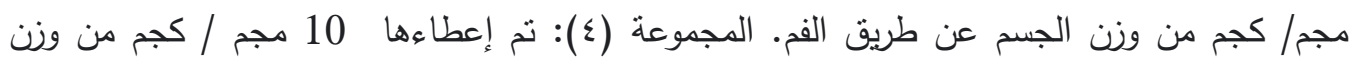
الجسم فلوريد الصوديوم (NaF) و تتخذي علي الغذاء الاساسي الددعم بـ ه ٪ من مسحوف فاكهة النبق.

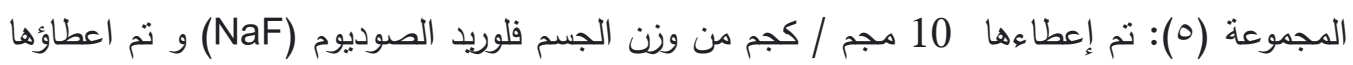

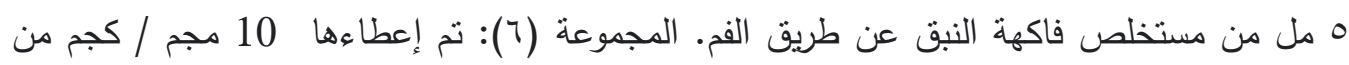

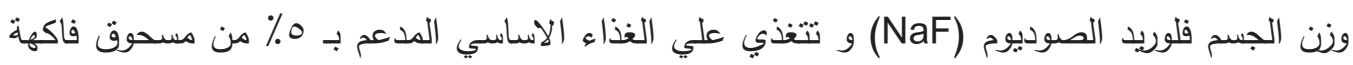

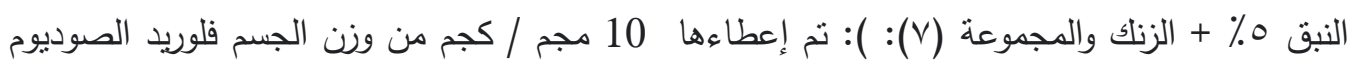
(NaF)

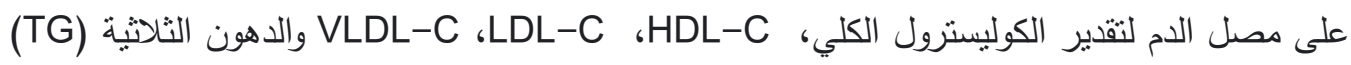

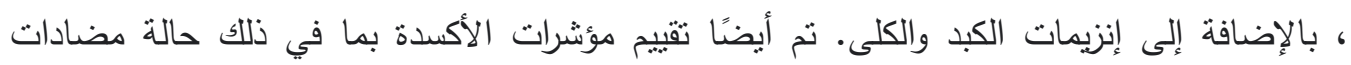

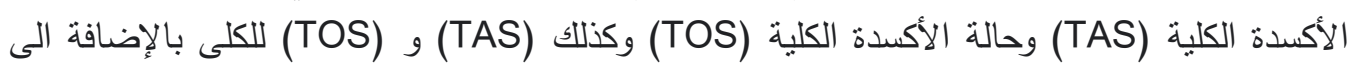

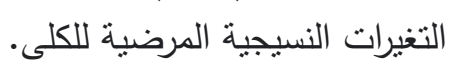
النتائج: أظهرت نتائج مجموعات NaF تغيرات كبيرة في المؤشرات البيوكيميائية مع انخفاض كبير في

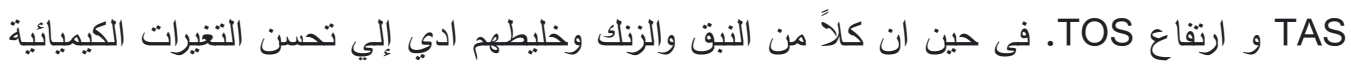

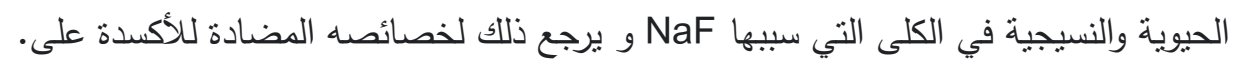

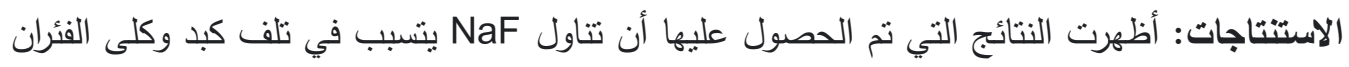

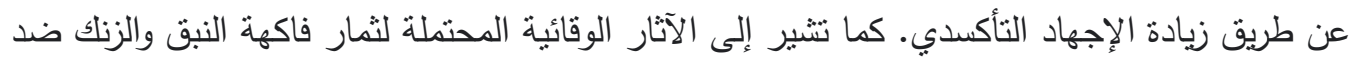
الإجهاد التأكسدي الناجم عن الفلوريد. الكلمات المفتاحية: فلوريد الصوديوم، النبق، الزنلك، الإجهاد النأكسدي، 